\title{
Тамгопользование в культуре тувинцев: древность, традиционность и современность
}

\author{
Чойган Г. Ондар, Саида Л. Бырыннай, \\ Национальный музей имени Алдан-Маадыр Республики Тыва, \\ Российская Федерация \\ Аржаана Ч. Тюлюш, \\ Муниципальная общеобразовательная школа № 1 г. Шагонара, Российская Федерация
}
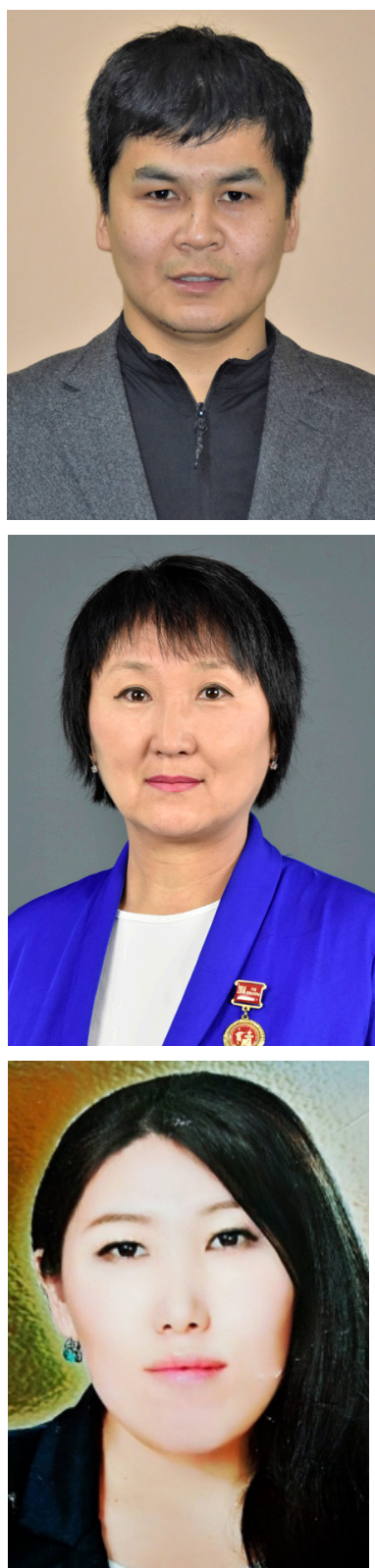

Тамги как ранние памятники историко-культурного наследия имеют огромное историографическое значение, ввиду того, что они были широко распространены и бытовали длительное время на территории степной полосы Евразии. В свете относительно новых находок тамг скифского времени в кургане Аржан-2, на стелах и среди петроглифов Тувы интересно сравнительное изучение древних, традиционных и современных тамг. В данной статье проведён сравнительно-сопоставительный анализ тамговых знаков, которыми пользовались ранние кочевники Тувы, с традиционными и современными тамгами тувинцев. Для этого привлечены археологический и этнографический материалы. Основными источниками по традиционным и современным тамгам стали материалы полевых экспедиций в тувинские скотоводческие хозяйства в 2014 и 2020 г2.

Тамги скифского периода в Туве обычно обнаруживаются на стелах, скалах, личных предметах, конском снаряжении. Самая ранняя находка тамги скифского периода на территории Тувы была обнаружена в ходе раскопок кургана Аржан-2 (VII в. до н. э.) в «царской» могиле на золотой гривне и на фрагменте рогового псалия. Вероятно, в это время уже имелись устойчивые обширные традиции тамгопользования.

В традиционной и современной культуре тувинцев тамгопользование тесно связано с таврением скота. В условиях традиционной родоплеменной организации кочевой жизни тувинцев тамги служили маркерами права собственности на скот. И несмотря на отсутствие в современных реалиях острой практической необходимости в тамгах, тувинцы сохраняют тамгопользование как культурный элемент, хотя и в гораздо меньшем масштабе, чем раньше, в начале $X X$ в.

Можно отметить некоторую устойчивость форм тамговых знаков, почти все базовые традиционные тувинские тамги имеют аналогии со скифскими. Помимо основной формы, также устойчиво сохраняются некоторые дополнительные тамгообразующие элементы. Несмотря на это, семантика некоторых тамг, вероятно, меняется. Значительное влияние на традиционное тамгопользование и тамгообразование оказали появление письменности и советская политика. Таким образом, традиция тамгопользования народов, населявших территорию современной Тувы, уходит корнями в глубокую древность, по крайней мере, вплоть до эпохи ранних кочевников.

Ключевые слова: тамга; тамгопользование; тамгообразующий элемент; петроглиф; тавро; скифская культура; тувинская культура; Тува; тувинцы

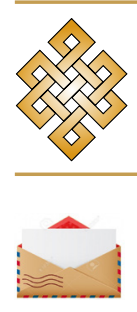

Для цитирования:

Ондар Ч. Г., Бырыннай С. Л., Тюлюш А. Ч. Тамгопользование в культуре тувинцев: древность, традиционность и современность // Новые исследования Тувы. 2021, № 1. C. 107-130. DOI: https://www.doi.org/10.25178/nit.2021.1.6

Бырыннай Саида Лопсановна - хранитель 1 категории отдела учета и хранения фондов Национального музея им. Алдан-Маадыр Республики Тыва. Адрес: 667000, Россия, г. Кызыл, ул. Титова, д. 30. Тел.: +7 (394-22) 2-28-04. Эл. адрес: saidabyrynnaj-68@mail.ru

Тюлюш Аржаана Чамбаловна - учитель истории и обществознания МБОУ СОШ №1 г. Шагонар Улуг-Хемского района Республики Тыва. Адрес: 668210, Россия, г. Шагонар, ул. Октябрьская, д. 32. Тел.: +7 (394) 362-18-50. Эл. aдрес: tyulyush. arzhaana@mail.ru 


\title{
The uses of tamga in Tuvan culture: Antiquity, traditionalism and modernity
}

\author{
Choigan G. Ondar, Saida L. Byrynnai \\ Aldan Maadyr National Museum of the Republic of Tuva, Russian Federation, \\ Arzhaana Ch. Tyulyush \\ Comprehensive school No.1, Shagonar, Russian Federation
}

Tamgas as early items of historian and cultural heritage are of huge importance for historiographers, since they were widespread for a long period of time throughout the Eurasian steppes. In the light of relatively recent discoveries of tamgas of the Scythian times in Arzhan II kurgans, stelae and on Tuvan petroglyphs, old, traditional and contemporary tamga signs are becoming an attractive object for a comparative study. In this article, we aim to study the tamgas in use among early Tuvan nomads in comparison with traditional and contemporary signs in use among Tuvans. Also relying on archaeological and ethnographic materials, we have taken data from field expeditions to Tuvan cattle farms in 2014 and 2020 as our main source.

Scythian period tamgas in Tuva are most frequently found on stelae, rocks, personal objects and horse harness. The earliest find of such type was the one made in the 7th century BC Arzhan II kurgan. In the "royal" grave, tamgas were discovered on a gold torque and on a fragment of a horn shank. A widely established tradition of tamga use must have been in place by then.

In both traditional and contemporary Tuvan culture the use of the tamga has always been inseparable from branding cattle. Under traditional family organization of Tuvan nomadic life, tamgas were used as prove of ownership rights. And even though there is no acute practical need to keep using them now, Tuvans have preserved tamgas as an element of culture, used as they are less frequently than in early 20th century.

The forms of the tamga signs have been found to be quite stable, with almost all base tamga shapes having a close Scythian counterpart. Besides base shapes, some add-on elements have also been preserved - but the semantics of some tamgas must have significantly changed. Traditional tamga use and tamga-making rules have felt a strong impact of the arrival of writing and the policies of the Soviet Union. Thus tamga use among the peoples of contemporary Tuva is rooted in deep antiquity, going back at least to the early nomadic age.

Keywords: tamga; use of tamga; tamga's formative element; petroglyph; brand iron; Scythian culture; Tuvan culture; Tuva; Tuvans

For citation:

Ondar Ch. G., Byrynnai S. L. and Tyulyush A. Ch. The uses of tamga in Tuvan culture: Antiquity, traditionalism and modernity. New Research of Tuva, 2021, no. 1, pp. 107-130. DOI: https://www.doi.org/10.25178/nit.2021.1.6

ONDAR, Choigan Gennadievich, Academic Secretary, Aldan Maadyr National Museum of the Republic of Tuva. Postal address: 30 Titov St., 667000 Kyzyl, Russian Federation. Tel.: +7 (394-22) 2-28-04. Email: choygandi@mail.ru ORCID ID: 0000-0001-5779-4217

BYRYNNAI, Saida Lopsanovna, Custodian, Department of Registering and Storing of the Collections, Aldan Maadyr National Museum of the Republic of Tuva. Postal address: 30 Titov St., 667000 Kyzyl, Russian Federation. Tel.: +7 (394-22) 2-28-04. Email: saidabyrynnaj-68@mail.ru

TYULYUSH, Arzhaana Chambalovna, teacher of History and Society Studies, Comprehensive school No.1, Shagonar, Ulug-Khem rayon, Republic of Tuva. Postal address: Oktyabrskaya St., 668210 Shagonar, Russian Federation. Tel.: +7 (394) 362-18-50. Email: tyulyush.arzhaana@mail.ru 


\section{Введение}

В последние годы исследователи все больше внимания уделяют изучению явления тамгопользования. Сам феномен тамгопользования определяется «как социально-политическое и экономическое явление, в рамках которого для различения своих и чужих, для маркировки значимой коллективной и личной собственности, партий товаров и подарков, для демонстрации социального статуса и личных заслуг, для наглядного подтверждения участия человека или группы людей в неких общественно значимых акциях использовались особые визуальные метки / знаки / эмблемы» (Тамги доисламской ..., 2019: 21). Тем самым подчеркивается, что подобная маркировка имеет не только бытовое значение, но и широкое культурное.

По вопросу раннего бытования и функционального назначения тамг в Туве есть работы, посвященные интерпретации древнетюркского тамгового материала (Кызласов, 1960; Кляшторный, 1980; Кормушин, 1997; Щербак, 2001; Васильев, 2015; Тишин, 2018). Отдельные тамги из скопления петроглифов Тувы М. А. Дэвлет отнесла к эпохе ранних кочевников (Дэвлет, 1976: 38-40; 1980: 239; 1998 : 190, рис. 16; 2009: 203). Тема тамгопользования в традиционной культуре тувинцев XIX - начала XX в. фрагментарно рассматривается в работах, посвященных истории и этнографии тувинцев: Н. Ф. Катанова, В. В. Радлова, В. И. Дулова, С. И. Вайнштейна (Радлов, 1905; Дулов, 1956; Вайнштейн, 1972; Катанов, 2011). Работы тувинских исследователей В. К. Даржа, С. Ч. Донгак, Б. Б. Монгуш (Даржа, 2003; Донгак, 2010; Монгуш, 2015ab), в том числе и одного из соавторов этой статьи, А. Ч. Тюлюш, также содержат материал, охватывающий XIX - середину XX в. (Тюлюш, 2014, 2015, 2016). Современное состояние тамгопользования тувинцев-скотоводов до сих пор объектом научных исследований не становилось, в том числе с исследованием определенных традиций. Так, в свете относительно новых находок тамг скифского времени в кургане Аржан-2, на стелах и среди петроглифов Тувы интересно сравнительно-сопоставительное изучение древних, традиционных и современных тамг. Вопрос влияния изобразительного искусства ранних кочевников на традиционные тамги и орнаментальное искусство тувинцев рассматривал С. И. Вайнштейн (Вайнштейн, 1974: 155-157, рис. 98, 101, 102). Он же высказал мнение о первичности орнаментов по отношению к тамгам (там же: 145). Общий сравнительно-сопоставительный анализ традиционных тамг со знаками на петроглифах, оленных камнях, курганных плитах Алтая и Хакасии проводили Е. Е. Ямаева (Ямаева, 2004), Л. Р. Кызласов, Н. В. Леонтьев (Кызласов, Леонтьев, 1980: 21-31).

Цель данной статьи - предложить сравнительно-сопоставительный анализ тамговых знаков, которыми пользовались ранние кочевники Тувы, с традиционными и современными тамгами тувинцев, в том числе анализ скифских сюжетов в тамгопользовании тувинцев.

Предлагается краткий обзор тамгообразных знаков ранних кочевников Тувы, представление традиционных и современных тамг тувинцев, а также сравнительно-сопоставительный анализ. Работа основана на применении исторического, сравнительного, социологического и статистического методов.

Для данной работы привлечены археологический и этнографический материалы Тувы. Источниками по традиционным и древним тамгам, которые позволили провести сравнительный анализ, стали работы Н. Ф. Катанова, С. Ч. Донгак, Б. Б. Монгуш, А. Ч. Тюлюш (Катанов, 2011; Донгак, 2010; Монгуш, 2015ab; Тюлюш, 2015), фондовые материалы Национального музея Республики Тыва: коллекция тавр, когээржиков, личная записная книжка В. П. Ермолаева, предметы с тамгообразными знаками из кургана Аржан-2, проанализированные археологами (Чугунов, Парцингер, Наглер, 2017), материалы по петроглифам и изображениям на стелах Тувы с тамгообразными знаками (Батманов, Арагачи, Бабушкин, 1962; Васильев, 1983; Грач, 1968; Дэвлет, 1976, 1980, 1998, 2004, 2009). Основными источниками по традиционным и современным тамгам стали полевые этнографические материалы авторов, собранные во время экспедиций в тувинские скотоводческие хозяйства в 2014 г. (УлугХемский, Овюрский, Эрзинский, Чаа-Хольский, Сут-Хольский кожууны) и 2020 г. (Дзун-Хемчикский, Кызылский, Тандинский, Пий-Хемский, Улуг-Хемский, Чаа-Хольский кожууны) (далее - ПМА, 2014 и ПМА, 2020).

\section{Находки тамгообразных знаков эпохи ранних кочевников}

Находки тамг скифского периода (IX-III вв. до н. э.) имеют особое значение ввиду чрезвычайной редкости. В Южной Сибири весьма богаты образцами тамгообразных знаков плиты оградок курганов тагарской культуры (VIII-I вв. до н. э.), распространенной в Республике Хакасия, Красноярском 
крае, Кемеровской области (Appelgren-Kivalo, 1931; Рыгдалон, 1959; Савинов, 1976, 1994; Николаева, 1983; Семенов и др., 2003). На Горном Алтае были найдены знаки-тамги на различных материалах, относимых к пазырыкской культуре (VI-III вв. до н. э.): знаки на деревянных деталях узды из разных курганов (Полторацкая, 1962); тамги, нанесенные на каменные стелы и балбалы (Кубарев, 1979: 145; 1987: 11-12, рис. 3, табл. LXVII); тамги на костяных стрелах (Кочеев, 1994: 58). Сводная таблица и первичная интерпретация алтайских тамг пазырыкской культуры приведены у С. А. Яценко (Яценко, 2001: 105-106, рис. 35-а).

Что касается тамгообразных знаков Тувы, датируемых временем ранних кочевников, здесь можно упомянуть знаки, названные в литературе «добуквенными знаками», на двух стелах в оградках курганов из урочища Хачы-Хову (рис. 1, элементы 16-20) и среди петроглифов у с. Хандагайты Овюрского кожууна (рис. 1, элементы 14-15) (Батманов, Арагачи, Бабушкин, 1962: 25-27; Грач, 1968: 209; Кызласов, 1977: 44-46; Васильев, 1983: 40, 74, 117), а также тамгообразный знак на золотой гривне (см. рис. 1, элемент 21, фото 1) и на фрагменте рогового псалия, обнаруженные в ходе раскопок кургана Аржан-2

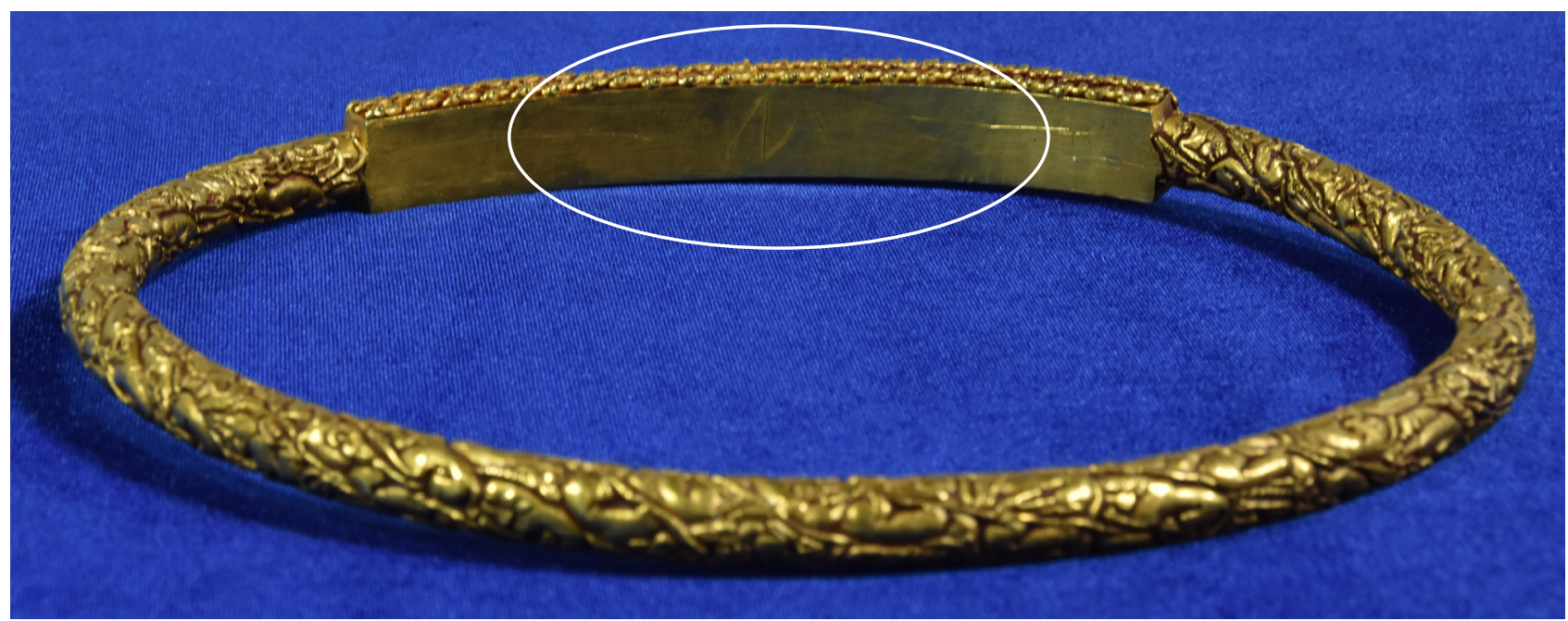

Фото 1. Тамгообразный знак на гривне скифского царя из могилы 5 кургана Аржан-2. Пий-Хемский район, Республика Тыва. Хранится в Национальном музее Республики Тыва, основной фонд, книга поступления № 11195/575, дата поступления 16 марта 2007 г. Фото Ч. Г. Ондар, 2020 г.

Photo 1. A tamga-like sign on the torque of a Scythian king from burial 5 in Arzhan II kurgan, Piy-Khem rayon, Republic of Tuva. Preserved at the National Museum of the Republic of Tuva, Main collections, Incoming registry No. 11195/575, acquired March 16, 2007. Photo by Ch. G. Ondar, 2020.

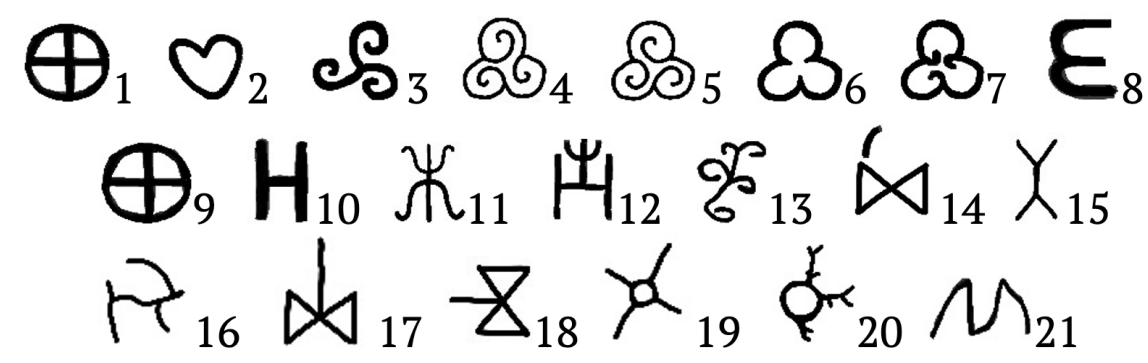

Рис. 1. Скифские тамги тувы.

1-2 - Мозага-Комужап (1 - Дэвлет, 2009: 64, табл. 12, камень 34; 2 - там же: 77, табл. 25, камень 62), 3 - Алдыьы-Мозага (Дэвлет, 1998: 99, табл. 17, камень 40), 4-6 - Куйлуг-Хем (Дэвлет, 1976: 115, табл. 72), 7-13 - Малый Баян-Кол (Чадамба, 2009: 205, табл. 1, табл. 2), 14-15 - Хандагайты (Батманов, Арагачи, Бабушкин, 1962: 25-27); 16-20 - Хачы-Хову (Грач, 1968: 209); 21 - Аржан-2 (Чугунов, Парцингер, Наглер, 2017: 374, табл. 36-1). Прорисовка Ч. Г. Ондар. Fig. 1. Scythian tamgas of Tuva.

1-2 - Mozaga-Komuzhan (1 - Devlet, 2009: 64, Table 12, stone 34); 2 - Ibid.: 77, Table 25, Stone 62), 3 - Aldyy-Mozaga (Devlet, 1998: 99, Table 17, Stone 40), 4-6 - Kuilug-Khem (Devlet, 1976: 115, Table 72), 7-13 - Maly Bayan-Kol (Chadamba, 2009: 205, Tables 1 \& 2), 14-15 - Khandagaity (Batmanov, Aragachi, Babushkin, 1962: 25-27); 16-20 - Khachy-Khovu (Grach, 1968: 209); 21 - Arzhan II (Chugunov, Partsinger, Nagler, 2017: 374, Table 36-1). Sketched by Ch. G. Ondar. 
(вторая половина VII в. до н.э.) (Čugunov, Parzinger, Nagler, 2006: 115-117, Taf. 9-13; Čugunov, Parzinger, Nagler, 2010: Taf. 3, Taf. 36: 1, Taf. 152), скопление тамгообразных знаков, которые встречаются среди петроглифов верховья Енисея, выполненные почти исключительно в «точечной технике», основную массу которых М. А. Дэвлет относит к скифскому времени (Дэвлет, 1976: 31, 32; 1998: 185): Куйлуг-Хем (рис. 1, элементы 4-6) (Дэвлет, 1976: табл. 72), Алдыы-Мозага (Дэвлет, 1998: 45-46, табл. 17, камень 40), Мугур-Саргол (рис. 1, элементы 4-6) (Дэвлет, 1980: 31, табл. 23; там же: 32, табл. 24), Мозага-Комужап (рис. 1, элементы 1-2) (Дэвлет, 2009: 77, табл. 25, камень 62; там же: 64, табл. 12, камень 34), Малый Баян-Кол (рис. 1, элементы 7-13) (Адрианов, 1886: 404-405; Богатырев, 1942; Дэвлет, 1996; Чадамба, 2009).

Среди петроглифов Тувы есть и другие знаки, датировка которых не установлена. Интерпретация этих материалов должна составить предмет специального исследования. Появление тамг у ранних кочевников можно отнести, по крайней мере, ко второй половине VII в. до н. э., пока не будут найдены более ранние. Тамги скифского периода в Туве обычно обнаруживаются на стелах, скалах, личных предметах, конском снаряжении. Вероятно, в это время уже имелись устойчивые обширные традиции тамгопользования.

\section{Тамгопользование в традиционной культуре тувинщев}

В традиционной культуре тувинцев в условиях родоплеменной организации кочевой жизни тамги играли значительную роль в хозяйстве и в быту, являясь отличительными, опознавательными знаками. Известно, что у каждого рода была своя определенная тамга (Катанов, 2011: 111; Даржа, 2003: 64). Ко времени первых этнографических исследований в Туве традиционные тамги сохранились в основном как тавро (тув. демдек, таңма) для клеймения скота. Ими отмечали не только лошадей, но и волов, «употребляемых для верховой езды» (Катанов, 2011: 126). Интересно, что самые ранние тамги в Туве, изображенные на крупе лошади и оленей, найдены среди петроглифов Малого Баян-Кола, датируемых позднескифским и гунно-сарматским временами. По стилистическим характеристикам изображения на памятнике ближе к минусинским (Чадамба, 2009: 206-207). Действительно, тамги на крупе лошадей довольно часто встречаются в памятниках таштыкской культуры (см.: Панкова, 2008: 107-108, рис. 1, 2). Тамги на крупе лошадей также известны по наскальным изображениям древнетюркского времени на территории Алтая (Черемисин, 2002: 14, рис. 5; Черемисин, 2004: 44, рис. 7; Кубарев, 2007: 284, рис. 1, элемент 5). Намного более поздние изображения лошадей с тамгами на скалах Мугур-Саргола в Туве М. А. Дэвлет относит к этнографической современности (Дэвлет, 1980: 26, табл. 16). Вероятно, появление традиции таврения лошадей можно отнести к позднескифскому времени.

B конце XIX - начале XX в. тамги указывали на принадлежность определенным сумонам (Дулов, 1956: 154; Вайнштейн, 1972: 78). Бытование сумонных тамг наряду с родовыми, вероятно, связано с действием в Туве маньчжурской административной системы (Донгак, 2010: 152). В то же время наряду с родовыми и сумонными бытовали личные (семейные) тамги богатых хозяев, которые создавались на основе существующих с добавлением отличительных элементов (Дулов, 1956: 155; Катанов, 2011: 111). Отличия в незначительных деталях по мнению С. И. Вайншейна могут также подтверждать этногенетические связи отдельных родов (Вайнштейн, 1972: 79). Еще одной особенностью тувинского традиционного тамгопользования (до периода Тувинской Народной Республики) является строгий контроль со стороны властей, «никто не имел права присвоить себе тамгу без разрешения» (Дулов, 1956: 154).

По начертанию элементов традиционные тамги тувинцев могут быть разделены на геометрический, растительный, зооморфный типы и знаки, изображающие предметы быта.

Самой распространенной тамгой досоветской Тувы был кас (гусь) (рис. 2, элемент 1) (Дулов, 1956: 155), применяемый во многих сумонах: Ховалыг, Донгак, Маады, Чооду (там же: 155), Оюн, Сат (Донгак, 2010: 153), Монгуш (Катанов, 2011: 111), Иргит и Соян (Тюлюш, 2015: 203).

Тамга алага, маска (молот) (рис. 2, элемент 2) была распространена в Центральной и Южной Туве в сумонах: Ондар, Тюлюш (Донгак, 2010: 153), Кыргыс, Тумат (Катанов, 2011: 111), Сат (ПМА, 20201), Донгак (ПМА, 2020²).

\footnotetext{
${ }^{1}$ Информанты: Сат Семен Сергеевич, 1985 г. р., м. Божуур-Даг, с. Хайыракан, Дзун-Хемчикский кожуун; Монгуш Роман Михайлович, 1970 г. р., г. Чадан, Дзун-Хемчикский кожуун.

${ }^{2}$ Информант: Донгак Александр Байыскланович, 1956 г. р., м. Тос-Булак Усту, Кызылский кожуун.
} 
Тамга кошкар (баран) (рис. 2, элемент 3) встречалась в сумонах: Иргит, Саая, Кыргыс (Донгак, 2010: 153), Ондар (Тюлюш, 2015: 204), Монгуш (ПМА, 20201).

Тамга сараакай (рис. 2, элемент 4) в различных вариантах была распространена в родах донгак, кыргыс (Монгуш, 2015а: 14-15).

Тамгу серээ (трезубец) (рис. 2, элемент 5) в основном использовали род ондар (Монгуш, 2015b: 106), также она распространена в Овюрском кожууне среди родов кыргыс, донгак, маады, тюлюш (Тюлюш, 2015: 204).

Тамга напчы (лист) (см. рис. 2, элемент 6) широко распространена среди родов оюн и соян (Донгак, $2010: 153)$ и практически отсутствует в западных кожуунах.

Тамга коргулчун (свинец), или арбак (горсть) (рис. 2, элемент 7) бытовала в сумонах Оюн (Катанов, 2011: 111), Долаан, Чыргакы-Куулар (Монгуш, 2015a: 14, 15), Биче-Ховалыг (Монгуш, 2015b: 106), в роду кыргыс (Монгуш, 2015а: 15).

Самыми распространенными тамгами, которые считаются появившимися в связи с буддийским влиянием, были шындамал (санскр. чинтаманиㄹ) (рис. 2, элемент 9), используемый в роду хомушку (Донгак, 2010: 153), сумоне Ак-Монгуш (ПМА, 2020³) и Адай Даа кожууна (Катанов, 2011: 281); дорума (рис. 2, элемент 10) (там же: 292, рис. 1).

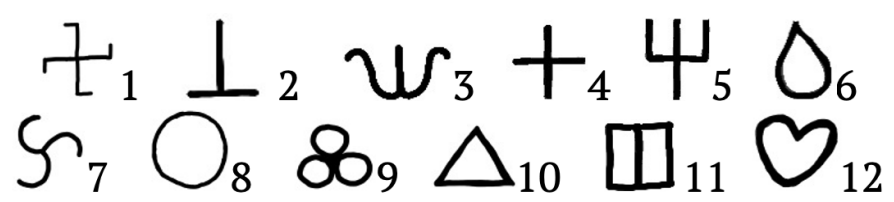

Рис. 2. Основные формы традиционных тамг тувинцев:

1 - кас (гусь), 2- алага (молот), 3 - кошкар (баран), 4-сараакай (крест), 5- серээ (трезубец),

6-напчы, или бүрү (лист), 7 - кургулчун, или арбак (свинец), 8- төгерик (круг), 9 - шындамал (чинтамани), 10 - дорума (торма), 11 - эжик, или хаалга (дверь, ворота), 12 - чүрек (сердие). Прорисовка Ч. Г. Ондар.

Fig. 2. The most popular shapes of traditional Tuvan tamgas:

1 - kas (goose), 2 - alaga (hammer), 3 - koshkar (ram), 4 - saraakai (cross), 5 - seree (trident), 6 - napchy / byry (leaf),

7 - kurgulchun / arbak (lead), 8-tegerik (circle), 9 - shyndamal (chintamani), 10 - doruma (torma), 11 - ezhik / khaalga (door or gate), 12 - chyrek (heart).

Sketched by Ch. G. Ondar.

Данные других исследователей и наши полевые исследования показали, что самыми многовариантными и распространенными являются тамги кас, алага, напчы, төгерик, эжик (хаалга), сараакай.

Тамга алага, например, имеет в Туве более 20 вариантов (см.: Тюлюш, 2015: 204). В наших полевых материалах интересны варианты: кошкарлыг алага (букв. 'молот с бараном') (ПМА, 20145), инек алагазы (букв. 'молот коровы'), дөрт ышкаш алага (букв. 'молот в виде цифры 4') (ПМА, 2014'), доңгактар алагазы (ПМА, 20207). К вариантам тамги кас, представленных у С. Ч. Донгак (Донгак, 2010: 153) можно добавить разновидность муңгаш кас (см. фото 3) (букв. 'закрытый гусь'), зафиксированный в 1915 г. В. П. Ермолаевым ${ }^{8}$. Остальные группы тамг имели значительно меньше подвидов. По нашему мнению, самые распространенные и многовариантные тамги могут быть самыми древними и базовыми.

В фондах Национального музея Республики Тыва хранятся несколько образцов традиционных тавр. Первые образцы (9 единиц) в фонды музея поступили в 1974 г.: шындамал, дорума, бүрү (напчы),

${ }^{1}$ Информант: Монгуш Роман Михайлович, 1970 г. р., г. Чадан, Дзун-Хемчикский кожуун.

${ }^{2}$ В индийско-буддийской мифологии магический камень, исполняющий желания.

${ }^{3}$ Информант: Монгуш Роман Михайлович, 1970 г. р., г. Чадан, Дзун-Хемчикский кожуун.

${ }^{4}$ Название конусовидного ритуального подношения в буддизме (прим. Ч. Г. Ондар).

${ }^{5}$ Информант: Тумат Оюн-оол Осур-оолович, 1945 г. р. с. Ак-Чыраа, Овюрский кожуун.

${ }^{6}$ Информант: Ооржак Эрес-оол Шактаржапович, 1944 г. р., с. Алдан-Маадыр, Сут-Хольский кожуун.

${ }^{7}$ Информант: Донгак Александр Байыскланович, 1956 г. р., м. Тос-Булак Усту, Кызылский кожуун.

${ }^{8}$ НМ РТ: ОФ, фонд В. П. Ермолаева, без номера. Топография: фонд «Документально-письменные источники», стеллаж 3, полка 6, папка 1. 


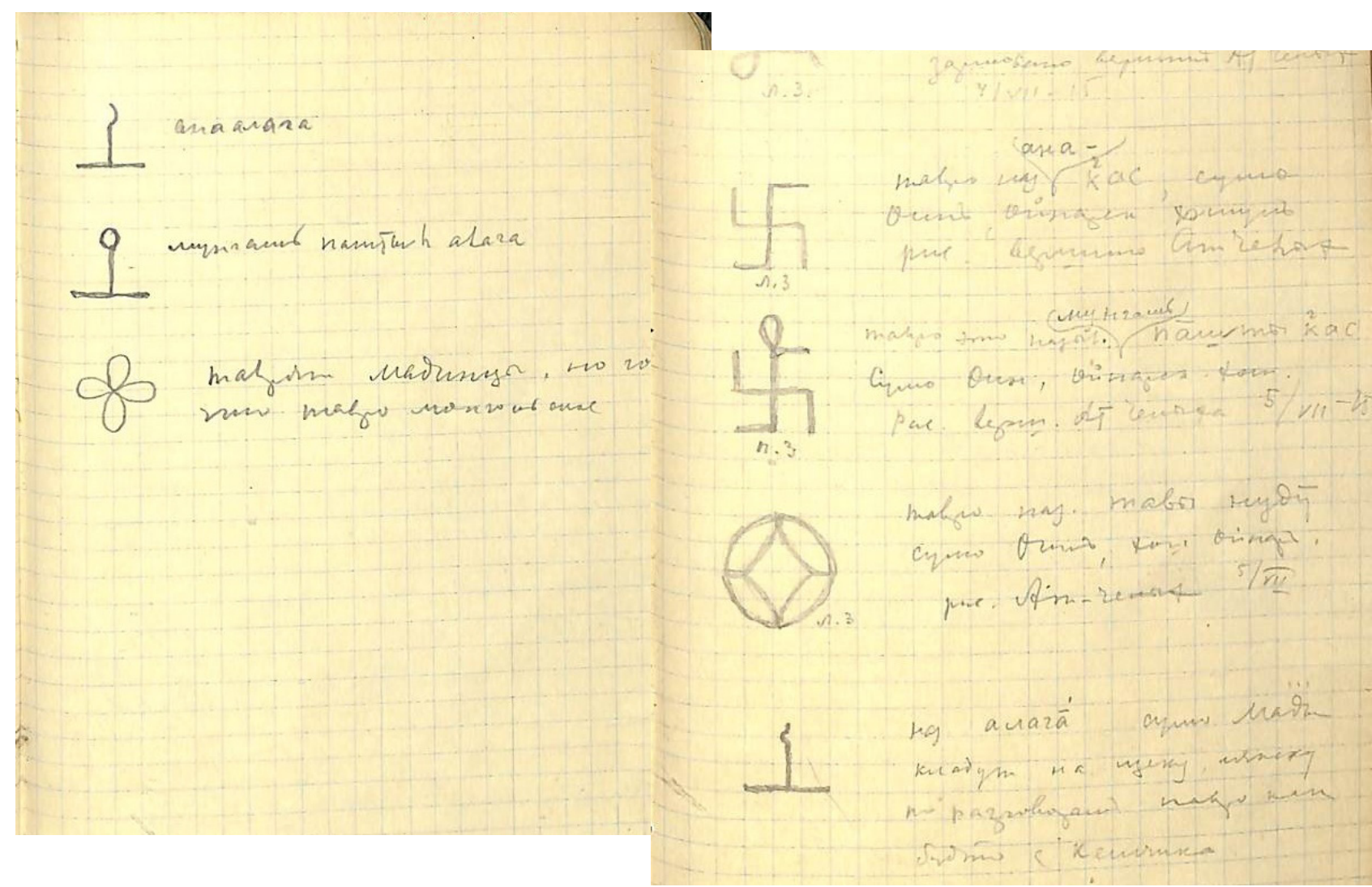

Фото 2 и 3. Страницы из записной книжки В. П. Ермолаева. 1915 г. НМ РТ, ОФ. Топография: фонд «Документально-письменные источники», стеллаж 3, полка 6, папка 1. Фото Ч. Г. Ондар, 2020 г.

Photos 2 and 3. Pages from V. P. Ermolaev's notebook, 1915. NM RT, Main Coll. Topography, "Documentary Written Sources" Fund. Bookcase 3, Shelf 6, File 1. Photo by Ch. G. Ondar, 2020.

шай, догуланчын демдектер, узун байлын, адыр баштыг алага, дегээ. Они были переданы кузнецом Сумбаа из сумона Ээрбек. Во время экспедиции в Улуг-Хемский район сотрудники ТНИИЯЛИ 1983-1984 гг. собрали и в 1986 г. сдали в фонды музея 63 предмета, относящихся к этнографии тувинцев, среди которых имеется одна тамга в виде буквы «Д» (фото 4). В 2019 г. заведующая музеем-филиалом с. Кунгуртуг Тере-Хольского кожууна С. Ш. Хомушку сдала еще 2 тамги (НМ РТ: ОФ, КП №№ 12318/53,54, дата поступления 22 июля 2019 г.).

Дополнительные элементы, видоизменяющие тамги. Прямая черта может добавляться практически в любую тамгу в любом количестве. Например, см. разновидности тамги шындамал (рис. 3, элементы 1 и 2) тамги рода монгуш (Монгуш, 2015b: 105, 106).

Закрывающий круг (муңгаш баштыг) является одним из самых используемых дополнительных знаков. Например, муңгаш баштыг алага (рис. 3, элемент 3) тамга сумона Тумат (Монгуш, 2015a: 15), муңгаш баштыг сараакай (рис. 3, элемент 4) - тамга рода донгак (там же: 14).

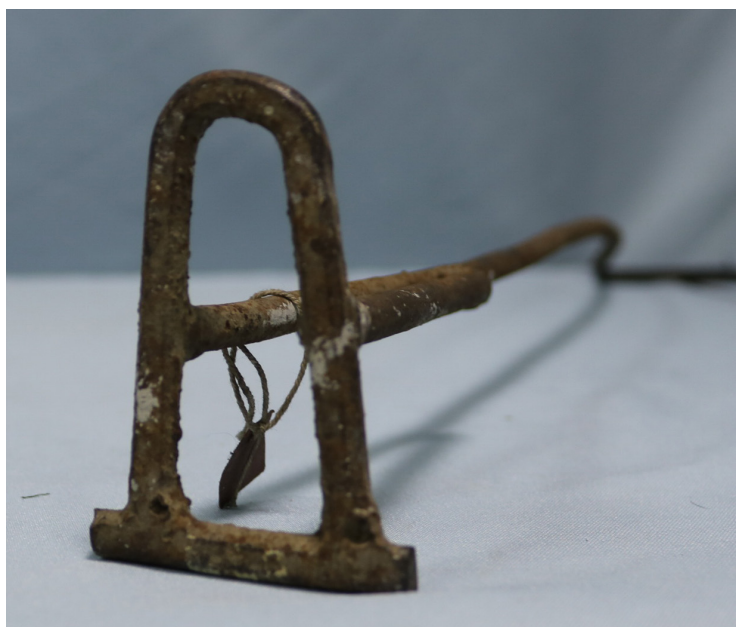

Фото 4. Тавро «Д» в коллекции Национального музея Республики Тыва. НМ РТ, ОФ, КП №№ 9255/44, дата поступления 3 июля 1974 г. Фото С. Л. Бырыннай, 2020 г. Photo 4. The ' $D$ ' brand iron in the collections of the National Museum. NM RT, Main Coll., Incoming registry No. 9255/44, Acquisition date July 3, 1974. Photo by S. L. Byrynnai, 2020. 
Часто используется дополнительный элемент - огонь (om), который обычно добавляется в верхней части тамги. K примеру, оттуг шындамал (рис. 3, элемент 5) - тамга сумона Хомушку Хемчикского кожууна (Монгуш, 2015b: 106) или тамга оттуг кас (рис. 3, элемент 6) сумона Сат Бээзи кожууна (Монгуш, 2015a: 15).

Еще одним продуктивным дополнительным элементом является ответвление (адыр). К тамгам с ответвлением, например, относится тамга адыр баштыг алага (рис. 3, элемент 7) рода кара-ондар (Монгуш, 2015b: 106).

Следующий дополнительный элемент - роговидное ответвление (мыйыстыг). Примером тамги с роговидным ответвлением можно назвать тамгу сумона Тумат Бээзи кожууна - ийи буттуг ширээлиг адыр алага (рис. 3, элемент 8) (Монгуш, 2015а: 15).

Такой же, как роговидный, но направленный вниз дополнительный элемент называется - усообразное (салдыг) ответвление. Тамга с усообразным ответвлением - салдыг сараакай (рис. 3, элемент 9) сумона Кыргыс (там же: 15).

Также нередко встречается луноподобное (айлыг) ответвление. Тамга с луноподобным ответвлением - айлыг алага (рис. 3, элемент 10) сумона Кыргыс Бээзи кожууна (там же: 15).

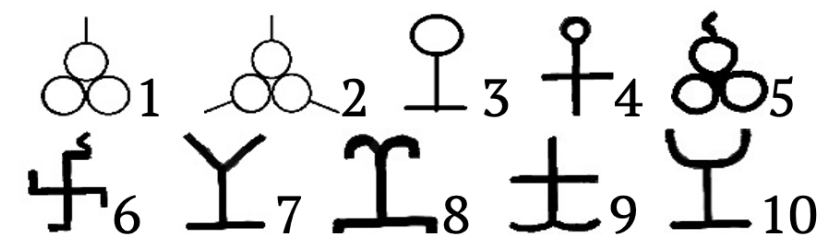

Рис. 3. Тамги с дополнительными элементами:

1 и 2 - шындамал (чинтамани), 3 - муңгаш баштыг алага (закрытый молот), 4 - муңгаш баштыг сараакай (закрытый крест), 5- оттуг шындамал (чинтамани с огнем), 6- оттуг кас (гусь с огнем), 7 - адыр баштыг алага (молот с ответвлением), 8 - салдыг сараакай (крест с усами), 9 - ийи буттуг ширээлиг адыр алага (молот с ногами и роговидным ответвлением), 10 - ай баштыг алага (молот с луной). Прорисовка 1-3 - А. Ч. Тюлюш, 4-10 - Ч. Г. Ондар. Fig. 3. Tamgas with add-on elements:

1-2 shyndamal (chintamani), 3 - muңgash bashtyg alaga (closed hammer), 4 - muygash bashtyg saraakai (closed cross), 5-ottug shyndamal (chintamai with fire), 6-ottug kas (goose with fire), 7 - adyr bashtyg alaga (hammer with an offshoot),

8 - saldyg saraakai (moustached cross), 9-iyi buttug shireelig adyr alaga (hammer with legs and a horn-like offshoot), 10 - ai bashtyg alaga (hammer and moon). Sketched by A.Ch. Tyulyush (1-3) and Ch. G. Ondar (4-10).

Традиция добавления дополнительных элементов к основному образу знака, вероятно, существует со скифских времен (рис. 1, элементы 13, 17 и 18), и, возможно, связана с уточнением владельца, будь то целое племя в составе этнокультурной общности или отдельная семья, или даже личность. Что касается традиционного тамгопользования тувинцев, то здесь такая традиция сохранилась (выше мы выделили несколько основных видов дополнительных элементов).

Итак, мы можем сказать, что к концу XIX в. в Туве использовались родовые, сумонные и личные (семейные) тамги, хотя восстановить полностью эту традицию сейчас представляется проблематичным в связи с нехваткой источников, их неполнотой. Сведения, полученные от современных информантов, содержат лишь отдельные упоминания о том, что было раньше в той или иной местности, которые могут содержать неточности.

\section{Изменения тамгопользования в ХХ в.}

В конце 1920-х - начале 1930-х гг. в Туве развернулись кардинальные социально-экономические перемены, в том числе началась борьба с пережитками прошлого, частью которых были родовые тамги (Дулов, 1956: 154). Ликвидировались зажиточные хозяйства, создавались госпредприятия, которые финансировались из бюджета (История Тувы, 2007: 230). Процессы кооперирования крестьянских и аратских хозяйств изменили принадлежность скота. К 1958 г., когда коллективизация сельского хозяйства области завершилась, удельный вес поголовья скота, находящегося в личной собственности, снизился до 10,8\% (История Тувы, 2016: 57, 58). 
Госхозы, колхозы, совхозы создали собственные метки-тамги, которые наносились рядом с тамгами прежних владельцев, например, у лошадей. Наш информант Р. М. Монгуш рассказал, что с образованием колхоза имени В. И. Ленина в с. Ийме, появилась тамга «ЛК» (Ленин колхоз), которой были отмечены все так называемые «раскулаченные» лошади, владельцы которых были «раскулачены», а имущество изъято. В то время ${ }^{1}$ практически каждая лошадь колхоза имела по две тамги: старую и метку ЛК (ПМА, 2020²). Так появились первые тамги в виде букв кириллицы.

Систематизация процесса таврения скота произошла, видимо, с развитием и укреплением крупных хозяйств - колхозов и совхозов в 1970-1980-е гг. в Тувинской АССР на фоне «интенсификации, специализации и концентрации производства, широкого внедрения хозрасчета и других методов ведения производства» (там же: 262). Каждый район, а внутри района каждый колхоз и совхоз имели свои номера, появились двузначные и трехзначные номера метки-тамги (ПМА, 20203). Так, «76»- значит, седьмой кожуун (Улуг-Хемский) и шестой совхоз (Арыскан) (ПМА, 20204). Процессы объединения и отделения совхозов приводили к изменениям меток-тамг. Например, от большого совхоза «Саянский» в Пий-Хемском районе, где лошадей отмечали цифрой «53», 1980-е гг. открепилось сесерлигское отделение. Отделившийся совхоз в с. Сесерлиг получил новые цифровую и буквенную метки-тамги «57» и «ССС» (т. е. Сесерлигский сельский совет). Позже при переименовании села в Германовка, меткой-тамгой стала уже «Г57» (ПМА, 20205).

С конца 1980-х - начала 1990-х гг. и по настоящее время идет обратный процесс, о чем пишет этнограф С. Ч. Донгак: «возрождаются традиции кочевого скотоводства, главным образом частная собственность на скот, и родовые тамги вновь стали востребованными» (Донгак, 2010: 156).

Отмеченные вехи изменения бытования традиции показывают, что история тамгопользования в целом, а в особенности история трансформации этой традиции в Туве в ХХ в., требует отдельного специального изучения, как в связи с общими социально-экономическими преобразованиями в республике, так и со сложной историей традиционного хозяйствования.

\section{Современные тамги тувинцев-скотоводов}

В 2020 г. мы побывали в 18 скотоводческих хозяйствах (аал) Дзун-Хемчикского, Чаа-Хольского, Улуг-Хемского, Пий-Хемского, Кызылского, Тандинского кожуунов, а также получили сведения от респондента из Тере-Хольского кожууна. Обобщение данных показало, что большинство владельцев скота тамгами не пользуется. Из 19 хозяйств, в которых мы провели опрос, только 8 - используют тамги. Из 11 аалов без тамг 6 только планируют создать и пользоваться. Остальные не изъявили желания использовать тамги и не чувствуют необходимости в них. Возможными причинами такой непопулярности тамг опрошенные называют: во-первых, снижение скотокрадства в республике за последние годы, а также тот факт, что украденный скот практически невозможно найти (воры его сразу забивают и разделывают); во-вторых, сложность выбора или создания тамги; в-третьих, сложность самого процесса таврения (ПМА, 20206).

Однако из данных хозяйств, в которых тамги используются, мы смогли составить некоторую обобщающую картину, в том числе типологизировать тамги. Их можно условно разделить на четыре типа:

I. традиционные тамги;

II. буквенные или числовые знаки, присвоенные колхозам и совхозам в советское время;

III. новые тамги;

IV. комбинированные тамги.

\footnotetext{
1 Учредительный хурал местных жителей о создании колхоза имени В. И. Ленина в с. Ийме состоялся 21 декабря 1950 г. См.: Монгуш, Д. Өгбелерниң тура-соруу [Сила духа предков] // Даа кожууннуң 240 чыл ою [240 лет Даа кожууну] / ред. А. С. Дембирель. Кызыл : б. и., 2005. 76 с. С. 24-27.

${ }^{2}$ Информант: Монгуш Роман Михайлович, 1970 г. р., г. Чадан, Дзун-Хемчикский кожуун.

${ }^{3}$ Информант: Хунай-оол Алим Олегович, 1985 г. р., м. Чыраа-Бажы, с. Ак-Туруг, Чаа-Хольский кожуун.

${ }^{4}$ Информант: Норбу Михаил Ховалыгович, 1960 г. р., м. Коктуг-Алаак, с. Арыскан, Улуг-Хемский кожуун.

${ }^{5}$ Информант: Тондуп Андрей Опей-оолович, 1969 г. р., с. Сесерлиг, Пий-Хемский кожуун.

${ }^{6}$ Информанты: Хунай-оол Алим Олегович, 1985 г. р., м. Чыраа-Бажы, с. Ак-Туруг, Чаа-Хольский кожуун; Тондуп Андрей Опей-оолович, 1969 г. р., с. Сесерлиг, Пий-Хемский кожуун.
} 
Традиционные родовые тамги. К традиционным тамгам мы относим все тамги, бытовавшие в тувинских хозяйствах до кардинальных перемен в 30-е гг. XX в., в том числе придуманные, заимствованные и видоизмененные. Здесь можно выделить два основных подтипа: унаследованная тамга и «присвоенная» тамга.

Унаследованная тамга может быть без изменений или с изменениями. По сведениям наших информантов, до сих пор без изменений используются, например, тамги:

- Чанагаш-Аксының ондарларының алагазы Ондара Чечек-оола, табунщика из с. Ийме ДзунХемчикского кожууна (рис. 4, элемент 1) (ПМА, 202011),

- cammap биле түлүштер алагазы Сата Сергея Сугеевича, табунщика из с. Хайыракан ДзунХемчикского кожууна (рис. 4, элемент 2) (ПМА, 2020²),

- донгактар алагазы Донгака Александра Байысклановича, проживающего в Кызылском кожууне в м. Тос-Булак Усту (рис. 4, элемент 3) (ПМА, 20203).

К традиционным тамгам с изменениями мы относим тавра, действительно когда-то принадлежавшие роду, но используемые сейчас с определенными изменениями. Например, тамга бижимел бичии А иштинде кас (знак кас, вписанный в рукописную строчную букву «А») М. Х. Норбу, проживающего в м. Коктуг-Алаак Улуг-Хемского кожууна. Здесь «А» обозначает его второе имя «Адыг-оол» и то, откуда он родом - из с. Арыскан (см. рис. 4, элемент 4) (ПМА, 20204).

К «присвоенным» мы относим тамги, не являющиеся унаследованными, а вновь созданные по образцу традиционных тамг или с заимствованием знаков у других. Соответственно здесь можно выделить два подтипа: вновь созданная и заимствованная. К вновь созданным можно отнести тамгу кошкар (рис. 4, элемент 5) в некоторых хозяйствах с. Хайыракан Дзун-Хемчикского кожууна. По словам P. М. Монгуша, эта тамга не является для них родовой, а придумана по образу и подобию традиционной тамги кошкар, и отличается большим размером и небольшим отростком под центральной вертикальной линией прототипной тамги (ПМА, 20205). В действительности, такую тамгу раньше называли кулактыг серээ (см.: Монгуш, 2015а: 14).

В качестве примера заимствованной тамги здесь можно привести тамгу дужамык ${ }^{6}$ (puc. 4, элемент 6), имеющейся в хозяйстве Монгуша Хулер-оола Байыр-ооловича. Он проживает в м. Шом-Шум Дзун-Хемчикского кожууна на левом берегу р. Хемчик. Животновод рассказал нашему информанту Р. М. Монгушу историю о том, что много лет назад в их аал однажды прибежали две молодые кобылы в поисках жеребца. На них имелась данная тамга. Хозяева так и не были найдены, несмотря на расспросы практически всех ближайших аалов. Так, кобылы остались в хозяйстве и со временем их потомство образовало целый табун. Тамга не просто осталась, ее стали наносить на других лошадей, ей даже придумали название (ПМА, 20207). Аналогии этой тамге мы не нашли в тувинском этнографическом материале. Подобные тамги, например, были у многих алтайских сеоков и называется сулук (удила) (Ямаева, 2004). Возможно, эти кобылы были из соседнего региона.

Буквенные или числовые знаки, присвоенные колхозам и совхозам в советское время. Они сейчас сохранились как тавра, указывающие на то, что владелец скота проживает или проживал в определенном населенном пункте, где раньше действовал колхоз или совхоз. По тому, как они сейчас используются, их можно условно разделить на три подтипа: номерная, буквенная и полная форма, т. е. включающая и цифры, и буквы.

Сохранили номерное тавро без использования буквенных обозначений, например, жители с. Ийме Дзун-Хемчикского кожууна. Скотоводческие хозяйства села активно используют цифровое тавро «31», а тавро «KM» (по названию совхоза имени «Карла Маркса») вышло из употребления (ПМА, 20208). Интересно, что в Дзун-Хемчикском кожууне некоторые табунщики специально ставят на свои машины государственные регистрационные знаки, дублирующие номерное тавро села: табунщик из с. Ийме -

\footnotetext{
${ }^{1}$ Информант: Монгуш Роман Михайлович, 1970 г. р., г. Чадан, Дзун-Хемчикский кожуун.

${ }^{2}$ Информант: Сат Семен Сергеевич, 1985 г. р., м. Божуур-Даг, с. Хайыракан, Дзун-Хемчикский кожуун.

${ }^{3}$ Информант: Донгак Александр Байыскланович, 1956 г. р., м. Тос-Булак Усту, Кызылский кожуун.

${ }^{4}$ Информант: Норбу Михаил Ховалыгович, 1960 г. р., м. Коктуг-Алаак, с. Арыскан, Улуг-Хемский кожуун.

${ }^{5}$ Информант: Монгуш Роман Михайлович, 1970 г. р., г. Чадан, Дзун-Хемчикский кожуун.

${ }^{6}$ Один из видов пута для фиксации передних ног лошади при выпасе (Даржа, 2003: 91).

${ }^{7}$ Информант: Монгуш Роман Михайлович, 1970 г. р., г. Чадан, Дзун-Хемчикский кожуун.

${ }^{8}$ Информант: Монгуш Роман Михайлович, 1970 г. р., г. Чадан, Дзун-Хемчикский кожуун.
} 
«031», из с. Баян-Тала - «030», из с. Бажын-Алаак - «032» (ПМА, 20201). Такая традиция распространена также в Кызылском кожууне, в с. Усть-Элегест (ПМА, 2020²). Однако это свойственно не всем кожуунам, информант из с. Ак-Туруг Чаа-Хольского кожууна уверил нас в том, что у них в селе такого явления нет $\left(\right.$ ПМА, $\left.2020^{3}\right)$. Более того, один из авторов этой статьи (Ч. Г. Ондар) заметил, что у некоторых жителей с. Ийме номера мобильных телефонов заканчиваются на «0031», что также, скорее всего, не случайно. Как видно, номерное тавро приобрело более широкое назначение, оно стало знаком групповой принадлежности, связанной с желанием наглядно показать принадлежность к «своим» и отличие от «других». И группу здесь образуют не все жители определенного сумона, а лишь та часть, интересы которой тесно связано с коневодством, представители которой и могут «читать» такие маркеры идентичности ${ }^{4}$.

Ярким примером использования только буквенного тавра является жители с. Хайыракан. Сохранилась тамга «X-H», а «34» уже никто не использует (ПМА, 20205).

Использование и цифр, и букв очень распространено. Например, жители с. Ак-Туруг Чаа-Хольского кожууна активно пользуются и цифрой «151», и буквами «АТ» (Ак-Туруг) (ПМА, 20206). Интересно, что при переезде в другой кожуун, некоторые сохраняют тамги своего села. Так, в Тандинском кожууне есть большой табун с тамгой-меткой «YК 25», принадлежащий семье, переехавшей туда из с. Арыг-Узуу Улуг-Хемского кожууна (ПМА, 20207).

Новые виды тавр. Отсутствие какой-либо систематизации, унификации и регистрации в тамгопользовании позволяет владельцам скота придумать любой знак в качестве личного тавра. Мы выявили три вида новых тамг: тамгоподобные знаки-тавро, буквенные знаки-тавро и художественный образ.

Тамгоподобные знаки-тавро можно разделить на два подтипа: собственно тамгоподобные знакитавро и буквенные тамгоподобные знаки-тавро. В качестве примера первого можно привести тамгу чүректиг удазын (букв. 'узел с сердцем') (рис. 4, элемент 14) информанта Ч. Х. Монгуша (ПМА, 20208). Тамга напоминает простую форму орнаментального узора өлчей удазыны ('узел счастья’) (Вайнштейн, 1974: 150, табл. № 64) с композиционным развитием в виде изменения боковых округлых элементов узора в сердцевидные.

Буквы в тамгоподобных тавро обычно являются начальными буквами имени или даже имени и фамилии владельца. Они могут быть двух типов: буквы, заключенные в геометрическую фигуру (обычно окружность); буквы, выстроенные как тамга. Примером тавра, оформленного заключением буквы в окружность, может быть тавро Найдана Ном-оола из Тере-Хольского кожууна: две буквы «Н» в окружности (рис. 4, элемент 17) (ПМА, 2020). Буквы могут быть выстроенными, как тамга. Пример: тавро Тулуша Борбак-оола из Дзун-Хемчикского кожууна, ТБ (см. фото 5, рис. 4, элемент 20) (ПМА, $\left.2020^{10}\right)$. Последний способ образования тамги характерен также для хакасов (Кызласов, Леонтьев, 1980: 27 , рис. $15-35,37-39,56)$.

Буквенные знаки-тавро. Как показывают наши наблюдения, более всего распространено образование тавр из букв. Буквы тибетского алфавита в качестве тамг среди тувинцев появились еще до начала XX в., например, род маады в качестве тамги использовал тибетскую букву $M A-\mathcal{V}$ (см. фото 3; Донгак, 2010: 155). Позднее буквенные тавра имели колхозы и совхозы. Примерно по такой же модели сейчас образуются тавра из букв кириллицы. Здесь можно выделить два подтипа: именные тавра и тавра, указывающие на определенное место.

В качестве тавр, обозначающей имя владельца, может быть: инициалы владельца, начальная буква имени владельца, начальная буква фамилии, начальные буквы имени и фамилии или даже фамилия

\footnotetext{
${ }^{1}$ Информанты: Монгуш Чук Хураган-оолович, 1971 г. р., м. Чангыс-Чодар, г. Чадан, Дзун-Хемчикский кожуун; Монгуш Агыжык Андреевич, 1998 г. р., м. Чодар, с. Бажын-Алаак, Дзун-Хемчикский кожуун.

${ }^{2}$ Информант: Тондуп Андрей Опей-оолович, 1969 г. р., с. Сесерлиг, Пий-Хемский кожуун.

${ }^{3}$ Информант: Хунай-оол Алим Олегович, 1985 г. р., м. Чыраа-Бажы, с. Ак-Туруг, Чаа-Хольский кожуун.

${ }^{4}$ В тувинском языке даже появился термин абт баштыг кижи (букв. 'человек с лошадиной головой'), т. е. человек фанатично увлекающийся вопросами коневодства, конных скачек и т. п.

${ }^{5}$ Информант: Сат Семен Сергеевич, 1985 г. р., м. Божуур-Даг, с. Хайыракан, Дзун-Хемчикский кожуун.

${ }^{6}$ Информант: Хунай-оол Алим Олегович, 1985 г. р., м. Чыраа-Бажы, с. Ак-Туруг, Чаа-Хольский кожуун.

${ }^{7}$ Информант: Ооржак Николай Романович, 1990 г. р., с. Бай-Хаак, Тандинский кожуун.

${ }^{8}$ Информант: Монгуш Чук Хураган-оолович, 1971 г. р., м. Чангыс-Чодар, г. Чадан, Дзун-Хемчикский кожуун.

${ }^{9}$ Информант: Чигжит Хулер-оол Геннадиевич, 1990 г. р., с. Кунгуртуг, Тере-Хольский кожуун.

${ }^{10}$ Информант: Монгуш Чук Хураган-оолович, 1971 г. р., м. Чангыс-Чодар, г. Чадан, Дзун-Хемчикский кожуун.
} 


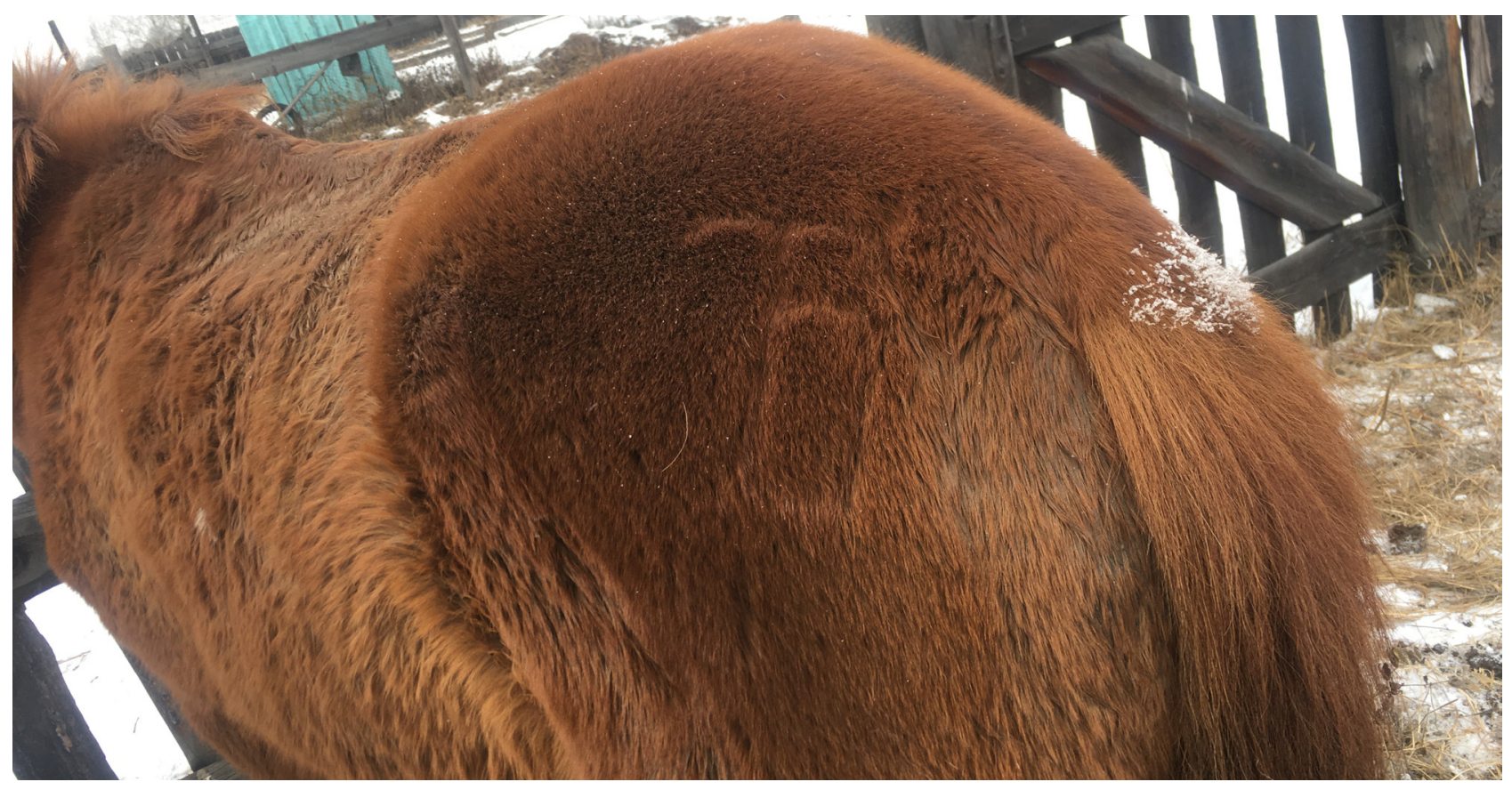

Фото 5. Личное тавро Б. Тулуш на лошади. 2020 г. Фото Ч. Г. Ондар. Photo 5. B. Tulush's personal brand iron mark on horseskin, 2020. Photo by Ch. G. Ondar.

полностью. Инициалы владельца - самый распространенный вид тавр. Как пример: тавро «ОКСК», принадлежавшую Ооржаку Ким-оолу Селбик-Караевичу, табунщику из г. Чадан, уже третье поколение его семьи использует в качестве семейной тамги (ПМА, 20201). В с. Сесерлиг есть тавро «Б», обозначающее начальную букву фамилии Бадарчы (ПМА, 2020²); в с. Кунгуртуг Тере-Хольского кожууна есть тавро «Д», обозначающее имя владельца - Дангыр-оол (ПМА, 20203); у братьев из Тандинского кожууна АйХаана и Аяна Кыргыса - тавро «AK» по начальным буквам имени и фамилии обоих братьев, имеющих общее хозяйство (ПМА, 20204); тавро «САТ» есть, например, у Кара-Сала Василия, проживающего в с. Хайыракан Дзун-Хемчикского кожууна, а «Сат» - это фамилия отца (ПМА, 20205).

В современной Туве появились тавра, созданные по образцу тавр колхозов и совхозов, обозначающие названия местностей. Буквенные знаки могут обозначать целый кожуун: например, «ТХК» - ТереХольский кожуун (ПМА, 20206); местность, название горы: «Б-Д» обозначает гору Баян-Дугай недалеко от с. Бажын-Алаак Дзун-Хемчикского кожууна (ПМА, 20207); вплоть до домашнего адреса: «Л91», что значит «ул. Лесная, д. 9, кв. 1» (ПМА, 2020).

Художественные образы. Единственный пример такого тавра мы встретили в Тере-Хольском кожууне в хозяйстве отца нашего информанта Х. Г. Чигжита. Там мы обнаружили тамгу в виде изображения головы лошади (рис. 4, элемент 29) (ПМА, 2020).

Комбинированные тамги. Очень часто в качестве тамги используется не одна тамга, а комбинация из нескольких разных типов тамг. И это сейчас больше правило, чем исключение. Причин появления комбинированных тамг может быть несколько. Во-первых, владелец может отметить лошадей несколькими тамгами с желанием показать не только на собственность, но и на принадлежность

\footnotetext{
${ }^{1}$ Информант: Монгуш Чук Хураган-оолович, 1971 г. р., м. Чангыс-Чодар, г. Чадан, Дзун-Хемчикский кожуун.

${ }^{2}$ Информант: Тондуп Андрей Опей-оолович, 1969 г. р., с. Сесерлиг, Пий-Хемский кожуун.

${ }^{3}$ Информант: Чигжит Хулер-оол Геннадиевич, 1990 г. р., с. Кунгуртуг, Тере-Хольский кожуун.

${ }^{4}$ Информант: Ооржак Николай Романович, 1990 г. р., с. Бай-Хаак, Тандинский кожуун.

${ }^{5}$ Информант: Монгуш Роман Михайлович, 1970 г. р., г. Чадан, Дзун-Хемчикский кожуун.

${ }^{6}$ Информант: Чигжит Хулер-оол Геннадиевич, 1990 г. р., с. Кунгуртуг, Тере-Хольский кожуун.

${ }^{7}$ Информант: Монгуш Агыжык Андреевич, 1998 г. р., м. Чодар, с. Бажын-Алаак, Дзун-Хемчикский кожуун.

${ }^{8}$ Информант: Монгуш Чук Хураган-оолович, 1971 г. р., м. Чангыс-Чодар, г. Чадан, Дзун-Хемчикский кожуун.

${ }^{9}$ Информант: Чигжит Хулер-оол Геннадиевич, 1990 г. р., с. Кунгуртуг, Тере-Хольский кожуун.
} 
к определенной местности или населенному пункту. Во-вторых, комбинированные тамги могут возникнуть при переходе лошади от одного владельца к другому. Комбинации могут быть разными.

Родовая тамга + тамга совхоза (села). Лошади табуна Монгуша Дайзы Байбековича из Дзун-Хемчикского кожууна отмечается тамгой «Бора-Хөл монгуштарының кошкары» (букв. 'баран рода монгуш из Бора-Холя') и совхозной меткой-тавро «31» (ПМА, 20201). Здесь традиционная тамга «кошкар» указывает на родовую принадлежность, а цифра «31» говорит о том, что владелец родом из с. Ийме. А их комбинация уже является личной узнаваемой тамгой - маркером собственности.

Родовая + личная тамга. Наш информант А. А. Монгуш рассказал, что у лошади его отца по кличке Калчан-Шилги, двукратного победителя Наадыма (1994, 1997 гг.), было две тамги - «щындамал» (чинтамани) и «МШБ» (инициалы брата хозяина лошади: Монгуш Шойдак Биченекович).

Тамга совхоза (села) + личная тамга. В с. Сесерлиг Пий-Хемского кожууна есть лошади с тамгами «CCС» и «M», где «M»- начальная буква имени владельца, а «ССС» значит «Сесерлигский сельский совет» (ПМА, 2020²).

Так, несмотря на долгую борьбу с «пережитками» феодального строя традиция таврения (в основном лошадей) среди скотоводов Тувы сохранилась, хотя и не во всех хозяйствах. Традиционными тамгами в качестве тавро пользуются в основном потомственные скотоводы-кочевники, линия передачи семейного ремесла которых не прерывалась. К сожалению, многие уже не знают, какая родовая тамга была в семье до периода кардинальных перемен в XX в., поэтому, начиная с 1990-х годов и до сих пор идет процесс создания новых личных форм тавро. Тавра, принадлежащие в свое время колхозам и совхозам, сохраняются среди скотоводов Тувы больше, как идентификаторы сумонной принадлежности.

\section{I. $\quad i_{1} \perp_{2} \stackrel{9}{3}_{3} \mathbb{P}_{4} \Psi_{5} \stackrel{9}{6}_{6} \delta_{7}$ II. $\quad 318$ X-H 9 AT 15110 YK 2511 CCC $12 \quad 5_{13}$ III. $\quad$ os $_{14} \mathbb{H}_{15} \mathbb{A}_{16} \mathbb{H}_{17} \mathbb{A}_{18} \mathbb{B}_{19} \overbrace{20}$ ОКСК21 Б22 IV. $\quad 31 \mathrm{~W} 30$ МШБ \&े 31 M CCC 32}

Рис. 4. Разновидности современных тамг тувинцев:

I. Традиционные: 1-7; ІІ. Буквенные или числовые знаки, присвоенные колхозам и совхозам в советское время: 8-13; III. Новые: 14-29; IV. Комбинированные: 30-32. Прорисовка Ч. Г. Ондар.

Fig. 4. Variation of contemporary Tuvan tamgas:

I. Traditional: 1-7; II. Letter or numeric signs assigned to kolkhozes and sovkhozes (collective farms) in the Soviet period: 8-13. III. Recently accepted: 14-29; IV. Combined: 30-32. Sketched by Ch. G. Ondar.

\section{Следы скифского влияния в тамгопользовании тувинцев}

Как мы уже упоминали, скифские тамги встречаются на различных предметах, начиная от бытовых предметов до скальных поверхностей. Тувинские традиционные тамги часто встречаются среди орнаментов предметов быта: сундуков, кожаных сосудов, тебеньков и т. д. Вероятно, тамги помимо орнаментальной функции, иногда выполняли также роль маркеров принадлежности предмета быта определенному человеку или семье. В фондах Национального музея Республики Тыва есть традиционные фляжки из кожи (көгээржик, хойлаарак), некоторые из которых помимо орнаментальных тамг

\footnotetext{
${ }^{1}$ Информанты: Монгуш Роман Михайлович, 1970 г. р., г. Чадан, Дзун-Хемчикский кожуун; Монгуш Чук Хураганоолович, 1971 г. р., м. Чангыс-Чодар, г. Чадан, Дзун-Хемчикский кожуун.

${ }^{2}$ Информант: Тондуп Андрей Опей-оолович, 1969 г. р., с. Сесерлиг, Пий-Хемский кожуун.
} 
имеют также отдельные тамги, нанесенные на основание горлышка (фото 6).

В пользу того, что они действительно являются маркерами собственности, указывает, например, дополнительная черта тамги кас.

Мы зафиксировали интересный случай использования метки в домашней утвари. Мама нашего информанта Ч. Х. Монгуша, Александра Бюрбюевна, в 1990-е - начале 2000-х гг. наносила краской метку «М» на алюминиевые бидоны, бочки, тазы, чтобы было легче находить свою посуду. Дело в том, что по соседству жили близкие родственники, и они друг у друга часто брали посуду, а посуда была одинаковой, заводского производства. При этом, по ее словам, «М» не значит ни «монгуш», ни даже буква. Это просто знак (ПМА, 202012). Такую традицию (помеченные краской ведра, тазы, бидоны) помнит у чабанов родственников в Тес-Хемском кожууне и Ч. К. Ламажаа 2 . Видимо, мечение предметов быта тесно связано с необходимостью разделения личной (семейной) собственности в условиях тесного общения нескольких семей. Сейчас, по всей видимости, такая необходимость в мечении предметов постепенно отпадает.

Еще одним явлением традиционной кочевой культуры Тувы, связанным с мечением скота, существующим, по крайней мере, со времен скифской эпохи (Руденко, 1952: 89), является им - выполнение надрезов на ушах лошадей (Вайнштейн, 1972: 80). Наиболее полный

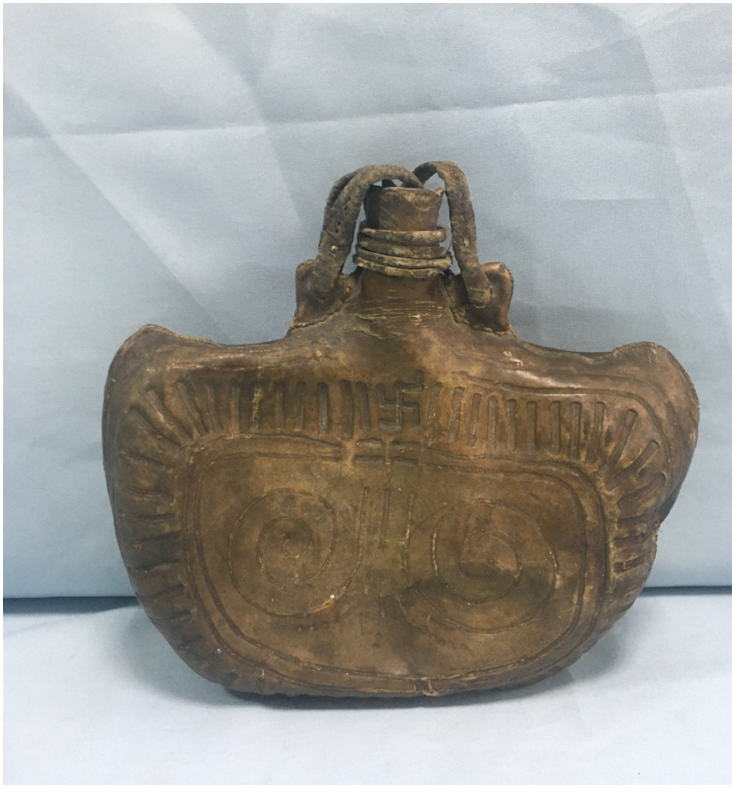

Фото 6. Көгээржик (кожаная фляжка) в коллекции Национального музея Республики Тыва. ОФ, КП № 11527/3, дата поступления, 21 июня 2011 г. Фото Э. Б. Нурзат, 2020 г.

Photo 6. A kegeerzhik (leather bottle) in the collections of the National Museum. NMRT, Main Coll, I ncoming register No. 11527/3, acquisition date June 21, 2011 Photo by E.B. Nurzat, 2020. обзор тувинских меток им представлен в работе В. К. Даржа (Даржа, 2003: 63, рис. 16). Здесь мы лишь упомянем о современном состоянии применения меток им на лошадях. Явление, как оказалось, сейчас достаточно редкое. Активно используют такой способ мечения лошадей, по словам нашего информанта Х.-Б. С. Бархоо, жители Эрзинского кожууна (ПМА, 2020³). Информанту А. О. Тондупу известно, что в с. Сесерлиг Пий-Хемского кожууна только в одном хозяйстве есть надрезы на ушах исключительно у кобыл (при этом отсутствует тавро). Верховым лошадям хозяева уши не надрезают по эстетическим соображениям (ПМА, 20204). В Дзун-Хемчикском кожууне такая традиция существовала до недавнего времени в тех хозяйствах, где не было личного тавра (ПМА, 20205). Как мы видим, эта традиция в современных реалиях постепенно утрачивается. И это касается только лошадей, а надрезы на ушах крупного и мелкого рогатого скота все еще является распространенным явлением.

\section{Сравнительный анализ скифских тамг с тувинскими традиционными и современными тамгами}

В таб. 1 представлен сравнительный анализ скифских тамг с тувинскими традиционными и современными тамгами: сюда же включены тамги, только внешне сходные, а также сходные по начертанию отдельных элементов.

Тамга төгерик (круг) (см. рис. 2, элемент 8) имеет самые древние корни (первая строка таблицы 1). Знаки, основным элементом которых является круг, имеют очень широкие территориальные и хронологические рамки. Появление таких тамгообразных знаков, вероятно, можно отнести к бронзовой эпохе, так как знаки-круги в большом количестве встречаются среди петроглифов Тувы, да-

\footnotetext{
${ }^{1}$ Информант: Монгуш Чук Хураган-оолович, 1971 г. р., м. Чангыс-Чодар, г. Чадан, Дзун-Хемчикский кожуун.

${ }^{2}$ Из устного сообщения Ч. К. Ламажаа авторам статьи, декабрь 2020 г.

${ }^{3}$ Информант: Бархоо Хат-Батор Сергеевич, 1983 г. р., м. Тос-Булак Усту, Кызылский кожуун.

${ }^{4}$ Информант: Тондуп Андрей Опей-оолович, 1969 г. р., с. Сесерлиг, Пий-Хемский кожуун.

${ }^{5}$ Информанты: Монгуш Роман Михайлович, 1970 г. р., г. Чадан, Дзун-Хемчикский кожуун; Монгуш Агыжык Андреевич, 1998 г. р., м. Чодар, с. Бажын-Алаак, Дзун-Хемчикский кожуун.
} 
тируемых бронзовой эпохой. Они также встречаются и среди скифских тамг (Семенов и др, 2003: 68, рис. 74). Кроме основной формы, среди тувинских традиционных тамг также встречаются и различные фигуры, вписанные в круг, которые могут быть признаны вариантами основной тамги төгерик. В круг также может быть вписана отдельная тамга, например, тамги кас (Донгак, 2010: 153) или сараакай (НМ РТ, КП 5967/3, дата поступления 03 июня 1974 г.). Наши наблюдения показывают, что круговая рамка является одной из самых популярных форм образования новых тамговых знаков в современной Туве (рис. 4, элементы 15-19). Причем такие тамги существуют в отдаленных друг от друга кожуунах республики, что говорит о независимости и отсутствии заимствований. Вероятно, этот древний способ образования новых форм тамг сохранился до наших дней.

Тамга сараакай (крест) (вторая строка таблицы 1) также имеет древние аналогии на всей территории Евразии. А. Е. Рогожинский относит знак-крест к андроновской группе (XVII-IX вв. до н. э.), северовосточная граница распространения которой доходит до Южной Сибири (Рогожинский, 2016: 56). На стеле из ур. Хачы-Хову Овюрского кожууна, датируемой скифским временем, есть знак, похожий на крест. В традиционном тамгопользовании тамга сараакай имела широкое распространение в Туве и являлась одной из базовых традиционных тувинских тамг с различными вариантами (см.: Монгуш, 2015a: 14-15). Она также была широко распространена на Алтае и в Хакасии (Ямаева, 2004: 9; Кызласов, Леонтьев, 1980: 27, рис. 15 элемент 1).

Также здесь нужно упомянуть тамгу кас (третья строка таблицы 1). В Туве бытует мнение, что этот знак в тувинской культуре указывает на буддийское влияние. Например, обладатель такой тамги, наш информант М. Х. Норбу, говорил о буддийском происхождении своей тамги (ПМА, 2020). Однако в пользу более древнего бытования этого знака на территории Саяно-Алтайского региона и Монголии говорит большое количество изображений этого знака на скалах и плитах оградок курганов, а также распространенность такой тамги у соседних народов - алтайцев (Ямаева, 2004: 10), хакасов (Кызласов, Леонтьев, 1980: 24), которые не были широко подвержены влиянию буддизма. Вероятно, этот знак появился на территории Саяно-Алтая в более ранее время. Более того название «гусь», сохранившееся во всех трех языках, указывает на орнитоморфную природу знака. Прототипами формы знака могут быть признаны, например, орнитоморфные знаки на плитах оградок тагарских курганов (Семенов и др., 2003: 63, рис. 68). Таким образом, возможно, тамга кас является одним из самых древних тамг, сохранившихся по сей день. Сохранение скифского знака - свастики среди тувинских тамг и орнаментальных мотивов отмечала также М. А. Дэвлет (Дэвлет, 1976: 39). Конечно, очевиден древний общий корень этих двух знаков. Видимо, знак кас существовал в Туве до принятия буддизма, а с утверждением буддизма она получила еще более широкое распространение среди местного населения. $\mathrm{K}$ сожалению, из-за схожести с фашисткой свастикой и ошибочным признанием ее буддийского происхождения, в XX в. она потеряла былую популярность. Даже сейчас сохраняется негативное отношение к этому знаку: он сразу ассоциируется со знаком фашисткой символики.

На скалах среди петроглифов Тувы чаще всего встречаются различные варианты скифского тамгообразного знака - триквестр (там же: 39) (рис. 1, элементы 3-7). Среди тувинских традиционных тамг на этот знак похожа тамга коргулчун, или арбак (четвертая строка таблицы 1). Она была широко распространена на всей территории Тувы и имелась у большинства основных тувинских родов западных кожуунов (Монгуш, 2015a: 14-15; 2015b: 106). Также определенную древнюю генетическую связь знак триквестр, возможно, имеет с тамгой шындамал (чинтамани), которая, как и в случае с тамгой кас, существовала в Туве до принятия буддизма, а с утверждением буддизма получила более широкое распространение. Интересно отметить наличие похожей тамги среди хакасов (Кызласов, Леонтьев, 1980: 27, рис. 15 элемент 51).

Аналогии тамге алага (пятая строка таблищы 1) имеются среди недатированных петроглифов Тувы (Дэвлет, 1980: 205, табл. 61, камень 283; 1998: 118, табл. 32, камень 87). Тем не менее, сложно сказать, имеются ли тут какие-то генетические связи между знаками. Аналогичная тамга есть у хакасов (Кызласов, Леонтьев, 1980: 27, рис. 15 элементы 2 и 3).

Аналогия распространенной тамги серээ (рис. 2, элемент 5) есть среди петроглифов Малого БаянКола (рис. 1, элементы 11 и 12), часть которых датируется позднескифским временем. Причем один из знаков визуально очень похож на современную тамгу (рис. 4, элемент 5). Таким образом, тамгу серээ тоже можно считать одной из древних (шестая строка таблицы 1).

${ }^{1}$ Информант: Норбу Михаил Ховалыгович, 1960 г. р., м. Коктуг-Алаак, с. Арыскан, Улуг-Хемский кожуун. 
Знак, похожий на треугольник (седьмая строка таблицы 1), встречается среди тамгообразных знаков на плитах тагарских курганов (Семенов и др., 2003: 11, рис. 5), среди традиционных алтайских тамг (Ямаева, 2004: 4), а также как составной элемент скифской тамги два треугольника, соединенные вериинами (рис. 1, элементы 13, 17 и 18). Такая тамга у тувинцев называется дорума. Но это не значит, что такая тамга появилась после принятия буддизма. Возможно, она в то время получила новое название в связи со схожестью с элементом буддийского ритуала.

Интересной представляется также история тувинской тамги чүрек (рис. 2, элемент 12) (Тюлюш, 2015 : 205, рис. 2-IX). Среди петроглифов Тувы есть копытообразный знак, напоминающий для современного человека «сердце» (Дэвлет, 2004: рис. 29-1-3; 2009: 77, табл. 25, камень 62). Такие же копытообразные знаки известны на территории Монголии, Казахстана, Саяно-Алтайского региона и др. (Членова, 2000; Китова, 2007) и практически везде они датируются скифским временем (восьмая строка таблицы 1). Вероятно, тувинская традиционная тамга чүрек бытовала с древнейших времен и сменила название сравнительно недавно под влиянием уже русской культуры. Этот скифский знак сохранился в тувинской традиционной и современной культуре как орнамент и тамга и как дополнительный элемент тамги (рис. 4, элемент 14). Форма знака устойчиво сохранилась, но семантика изменилась.

Самая древняя достоверно датируемая находка тамгообразного знака на гривне царя, напоминающий букву «М» (ширина знака - 20 мм, высота - 13 мм) (рис. 1, элемент 21; девятая строка таблицы 1), обнаружена в Туве в ходе раскопок кургана Аржан-2 (вторая половина VII в. до н. э.). Судя по расположению фигурок на переднем бруске, гривна носилась в одном положении, и поэтому, вероятно, знак «читался» только как «М». Он напоминает два горба верблюда-бактриана. Очевидно, что знак не являлся орнаментом, не предназначался для украшения гривны, так как нанесен на тыльной стороне и достаточно неаккуратно на фоне высокохудожественного рельефного декора самой гривны. На скалах среди петроглифов Тувы аналогичные знаки также встречаются (Дэвлет, 1976: 52, табл. 9, камень 198; 1980: 127, табл. 24, камень 134). Интересно, что в тувинском этнографическом материале есть орнамент (табл. 1, элемент 52), называемый теве мөгени (горб верблюда), или тевениң ийи мөгени (два горба верблюда) (Адыг-Тюлюш, 2017: 75, 93).

Судя по находкам из кургана Аржан-2, двугорбый верблюд хорошо знаком и значим для погребенных. 16 верблюдов изображены в первом ряду рельефного декора самой гривны (Чугунов, Парцингер, Наглер, 2017: 39, табл. 4-1). По одному верблюду есть в рельефных изображениях животных на стержнях золотых шпилек, найденных у головы царицы (там же: 58, табл. 55; 59, табл. 56). В кургане найдены также три литые бронзовые кольцевидные пронизи в виде головы верблюда (там же: 115 , табл. 142-1, 142-2, 142-3). Изображения верблюдов есть среди петроглифов на облицовочных плитах, найденных в кургане (там же: 135, рис. 112-3; 138, рис. 116-2; 139, рис. 118-4). Результаты анализа волокон текстильных находок кургана показали, что одним из распространенных материалов для изготовления одежды элитных слоев общества и ковров скифского времени была шерсть двугорбого верблюда (там же: 213, табл. XI).

Как видно, в кургане найдено много предметов, так или иначе, связанных с верблюдом и демонстрирующих значение этого животного для представителей царского клана или племени в целом. Вообще, образ верблюда занимает достойное место в искусстве скифо-сибирского звериного стиля, что очень подробно рассматривается в исследовании Е. Ф. Корольковой (Королькова, 2006: 84-104, табл. 50-57). По тому, какое значение ему придавали древние кочевники Евразии, верблюд вполне мог быть тотемным животным (Ямаева, 2004: 19-20) элитного скифского клана, представители которых погребены в кургане. Парциальные изображения, отражающие магический принцип «часть вместо целого», т. е. часть заменяет целое, хорошо представлены в искусстве ираноязычных народов в I тыс. до н. э., когда животное изображалось не целиком, а только отдельная его часть - голова или копыто коня, клюв или глаз орла и т. д. (Кузьмина, 1979: 43).

Кроме отдельных тамг, в традиционном и современном тамгопользовании сохранились также некоторые скифские тамгообразующие и видоизменяющие элементы. Об общем для скифского и тувинского тамгопользования способе образования тамг путем вписывания знаков в круг мы уже упомянули. Отдельными элементами, сохранившимися по сей день продуктивность в тамгообразовании, являются роговидное ответвление (десятая строка таблицы 1) и прямая черта (ср. табл. 1, элемент 43 и 7). 
Таблица 1. Сравнительная таблица скифских, тувинских традиционных и современных тамг. Прорисовка Ч. Г. Ондар Table 1. A comparative view of Scythian and Tuvan traditional and contemporary tamgas. Sketched by Ch. G. Ondar.

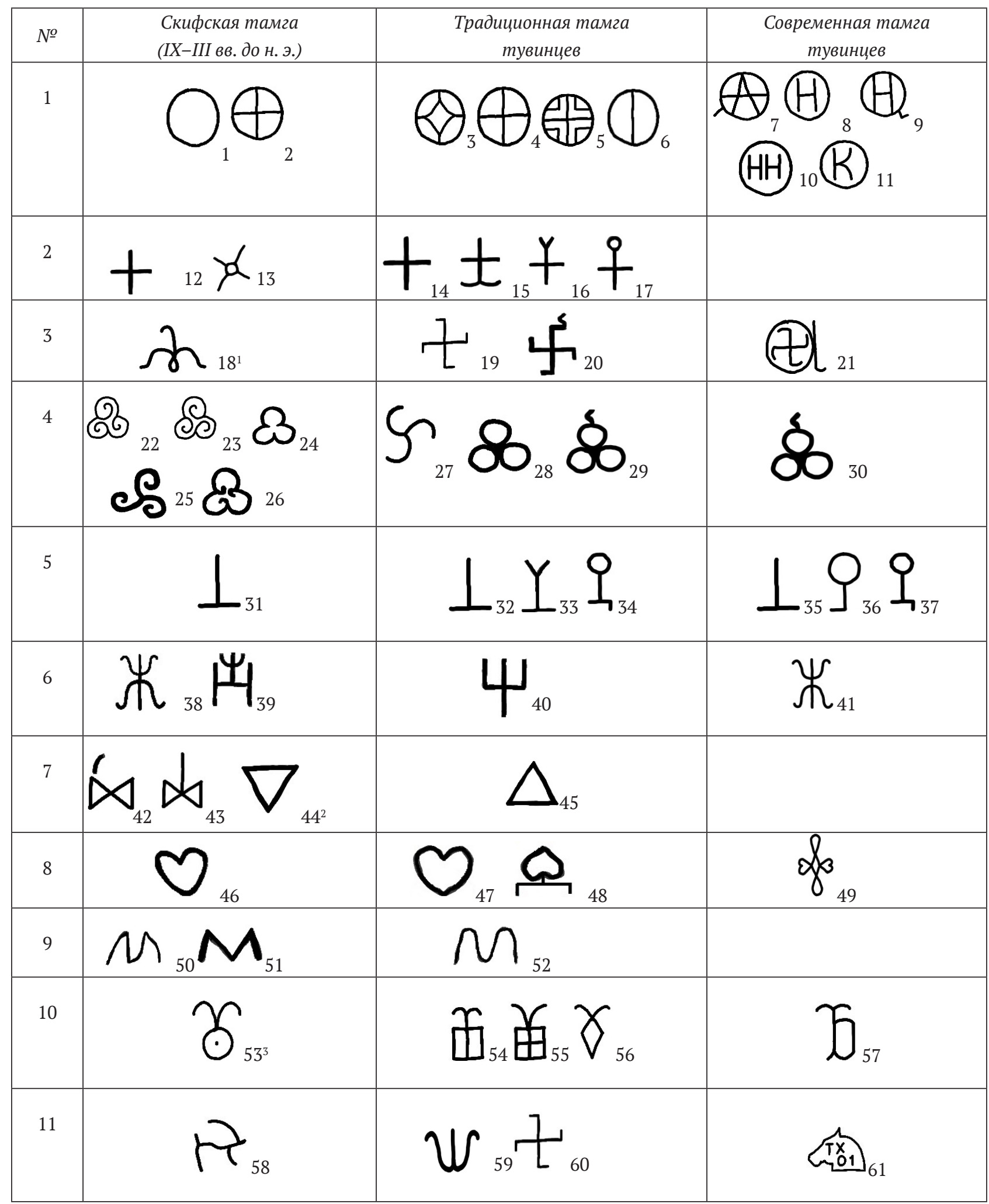

${ }^{1}$ См.: Семенов и др., 2003: 63, рис. 68.

${ }^{2}$ См.: там же: 63, рис. 68.

${ }^{3}$ См.: там же: 67, рис. 73, элемент 8. 
Влияние скифо-сибирского звериного стиля можно считать в целом важным аспектом тувинского тамгообразования (одиннадцатая строка таблицы 1). На это, в частности, указывает наличие определенного количества традиционных зооморфных тамг (рис. 2, элементы 1, 3 и 12), а также современной тамги в виде головы лошади (табл. 1, элемент 61).

\section{Заключение}

Таким образом, традиция тамгопользования народов, населявших территорию современной Тувы, восходит к эпохе ранних кочевников. Большое количество разновременных археологических памятников с тамгами и распространенность тамг в современной Туве свидетельствуют об устойчивой социально-экономической, и прежде всего культурной значимости явления тамгопользования для кочевых народов. Несмотря на отсутствие в современных реалиях острой практической необходимости в тамгах, тувинцы сохраняют тамгопользование как культурный элемент, хотя и в гораздо меньшем масштабе, чем раньше, в начале XX в. В современной Туве тамгопользование связано в основном с таврением лошадей.

Можно отметить некоторую устойчивость форм тамговых знаков, почти все базовые традиционные тувинские тамги имеют аналогии со скифскими. Помимо основной формы, также устойчиво сохраняются некоторые дополнительные тамгообразующие элементы. Несмотря на это, семантика некоторых тамг, вероятно, меняется. Значительное влияние на традиционное тамгопользование и тамгообразование оказали появление письменности и советская политика.

\section{Благодарности}

Авторы статьи выражают благодарность уважаемым животноводам Монгушу Роману Михайловичу, Монгушу Чуку Хураган-ооловичу, Чигжиту Хулер-оолу Геннадиевичу, Норбу Михаилу Ховалыговичу, Донгаку Александру Байысклановичу, Тондупу Андрею Опей-ооловичу, Монгушу Агыжыку Андреевичу, Хунай-оолу Алиму Олеговичу, Сату Семену Сергеевичу, Бархоо Хат-Батору Сергеевичу, Тумату Оюн-оолу Осур-ооловичу, Ооржаку Эрес-оолу Шактаржаповичу за консультации по традиционному и современному тамгопользованию тувинцев, а также Монгуш Александре Бюрбюевне за предоставленные материалы, Монгушу Яну Айсеновичу за помощь в прорисовке тамг.

\section{СПИСОК ЛИТЕРАТУРЫ}

Адрианов, А. В. (1886) Путешествие на Алтай и за Саяны, совершенное в 1881 году по поручению Императорского Русского географического общества членом сотрудником А. В. Адриановым. СПб. 423 с.

Адыг-Тюлюш, Л. С. (2017) Тыва чоннуң угулзалары, хээлери [Орнаменты тувинского народа]. Новосибирск : б. и. 180 с.

Батманов, И. А., Арагачи З. Б., Бабушкин Г. Ф. (1962) Современная и древняя енисеика. Фрунзе : Издательство Академии наук Киргизской ССР. 249 с.

Богатырев, Н. Г. (1942) О тувинских памятниках древности // Под знаменем Ленина - Сталина. № 2. С. 97-104.

Вайнштейн, С. И. (1972) Историческая этнография тувинцев / отв. ред. С. Г. Кляшторный. М. : Наука. 314 с.

Вайнштейн, С. И. (1974) История народного искусства Тувы / отв. ред. С. В. Иванов. М. : Наука. 224 с.

Васильев, Д. Д. (1983) Корпус тюркских рунических памятников бассейна Енисея / отв. ред. С. Г. Кляшторный. Л. : Наука. 128 с.

Васильев Д. Д. (2015) Древнетюркские надписи и петроглифы Южной Сибири как источник по истории периферии Тюркского каганата // Актуальные вопросы археологии и этнологии Центральной Азии: Мат-лы международной научной конференции. Улан-Удэ, 7-8 апреля 2015 г. / отв. ред. Б. В. Базаров. Иркутск : Изд-во «Оттиск». 504 c. С. $361-366$.

Грач, А. Д. (1968) Древнейшие тюркские погребения с сожжением в Центральной Азии // История, археология и этнография Средней Азии / ред. коллегия: А. В. Виноградов и др. М. : Наука. 368 с. С. 207-213.

Даржа, В. Ч. (2003) Лошадь в традиционной практике тувинцев-кочевников / отв. ред. Г. Н. Курбатский. Кызыл : ТувИКОПР СО РАН. 184 с.

Донгак, С. Ч. (2010) Некоторые аспекты изучения тувинских тамг // Проблемы этнической истории и культуры тюрко-монгольских народов : сборник научных трудов / отв. ред. Э. П. Бакаева. Элиста : КИГИ РАН. Вып. ІІ. 207 с. C. 151-157. 
Дулов, В. И. (1956) Социально-экономическая история Тувы в конце XIX - начале XX вв. М. : АН СССР. 608 с.

Дэвлет, М. А. (1976) Петроглифы Улуг-Хема / отв. ред. В. В. Волков. М. : Наука. 120 с.

Дэвлет, М. А. (1980) Петроглифы Мугур-Саргола / отв. ред. В. В. Волков. М. : Наука. 271 с.

Дэвлет, М. А. (1996) Петроглифы Енисея. История изучения (XVIII - начало XX вв.) М. : ИА РАН. 249 с.

Дэвлет, М. А. (1998) Петроглифы на дне Саянского моря (гора Алды-Мозага) / отв. ред. В. В. Волков. М. : Памятники исторической мысли. 287 с.

Дэвлет, М. А. (2004) Каменный «компас» в Саянском каньоне Енисея. М. : Научный мир. 88 с.

Дэвлет, М. А. (2009) Мозага-Комужап - памятник наскального искусства в зоне затопления Саянской ГЭС / отв. ред. М. Ф. Косарев. М. : Институт археологии РАН. 216 с.

История Тувы (2007) : в 3 т. / под общ. ред. В. А. Ламина. Новосибирск : Наука. Т. 2. 427 с.

История Тувы (2016) : в 3 т. / под общ. ред. Н. М. Моллерова. Новосибирск : Наука. Т. 3. 451 с.

Катанов, Н. Ф. (2011) Очерки Урянхайской земли. Дневник путешествия, исполненного в 1889 году. / отв. ред. К. А. Бичелдей. Кызыл : Музей антропологии и этнографии им. Петра Великого ; Тув. ин-т гуманитарных исследований. 384 с.

Китова, Л. Ю. (2007) Семантика знака копыта на тагарской бронзе // Каменная скульптура и мелкая пластика древних и средневековых народов Евразии : сборник научных трудов / отв. ред. А. А. Тишкин. Вып. 3. Барнаул : Азбука. 156 с. С. $28-30$.

Кляшторный, С. Г. (1980) Руническая надпись на каменном изваянии из Чойрэна // Страны и народы Востока / отв. ред. В. А. Ромодин. М. : Наука. Т. ХХІІ. Средняя и Центральная Азия. География, этнография, история. 278 с. C. $90-102$.

Кормушин, И. В. (1997) Тюркские енисейские эпитафии. Тексты и исследования. М. : Наука. 303 с.

Королькова, Е. Ф. (2006) Звериный стиль Евразии. Искусство племён Нижнего Поволжья и Южного Приуралья в скифскую эпоху (VII-IV вв. до н.э.). СПб. : Петербургское Востоковедение. 272 с.

Кочеев, В. А. (1994) Знаки на стрелах (К вопросу о назначении тамгообразных знаков на костяных наконечниках стрел из курганов Горного Алтая скифского времени) // Проблемы изучения культурно-исторического наследия Алтая / отв. ред. В. Н. Елин. Горно-Алтайск : Агентство по культурно-историческому наследию Республики Алтай. 117 с. С. $57-59$.

Кубарев, В. Д. (2007) Калбак-таш II: памятник наскального искусства Алтая // Проблемы археологии, этнографии, антропологии Сибири и сопредельных территорий. Материалы Годовой сессии ИАЭТ СО РАН 2007 г. / отв. ред. А. П. Деревянко, В. И. Молодин. Новосибирск: Изд-во Института археологии и этнографии СО РАН. Т. XIII. 524 с. С. 282-287.

Кубарев, В. Д. (1979) Новые сведения о древнетюркских оградках Восточного Алтая // Новое в археологии Сибири и Дальнего Востока / отв. ред. А. П. Погожева. Новосибирск : Наука. 237 с. С. 135-160.

Кубарев, В. Д. (1987) Курганы Уландрыка / отв. ред. В. Е. Медведев. Новосибирск : Институт истории, филологии и философии СО РАН. 300 с.

Кузьмина, Е. Е. (1979) Древнеиранские и переднеазиатские элементы в искусстве ираноязычных народов первой половины I тыс. до н. э. // Тезисы докладов III Всесоюзной конференции «Искусство и археология Ирана и его связь с искусством народов СССР с древнейших времен / отв. ред. Р. М. Поликарпова. М. : Советский художник. 96 с. С. $42-45$.

Кызласов, Л. Р. (1960) Новая датировка памятников енисейской письменности // Советская археология. № 3. C. 93-120.

Кызласов, Л. Р. (1977) «Древнетюркские» неурядицы // Советская тюркология. № 5. С. 44-46.

Кызласов, Л. Р., Леонтьев, Н. В. (1980) Народные рисунки хакасов / ред. Л. С. Ефимова. М. : Наука. 176 с.

Монгуш, Б. Б. (2015а) Бээзи кожуунннуң 17 сумуларының таңмалары [Тамги 17 сумонов Бейсэ хошуна] // Төөгүге даянмышаан - келир үеже (Бээзи кожууннуң 260 болгаш Хемчик кожууннуң 250 чыл оюнга тураскааткан эртемпрактиктиг конференцияларның материалдары. 2014 чылдың октябрь 24, 2015 чылдың апрель 29) [Опираясь на исторические знания - в будущее: Мат-лы научно-практических конференций, посвященных 260-летию Бэйсе хожуна и 250-летию Хемчикского хошуна. 24 октября 2014 г., 29 апреля 2015 г.] / отв. ред. С. М. Орус-оол. Кызыл : ОАО «Тываполиграф». 188 с. С. 13-16.

Монгуш, Б. Б. (2015b) Хемчик кожуунннуң 10 сумуларының таңмалары [Тамги 10 сумонов Хемчикского хошуна] // Төөгүге даянмышаан - келир үеже (Бээзи кожууннуң 260 болгаш Хемчик кожууннуң 250 чыл оюнга ту- 
раскааткан эртем-практиктиг конференцияларның материалдары. 2014 чылдың октябрь 24, 2015 чылдың апрель 29) [Опираясь на исторические знания - в будущее: Мат-лы научно-практических конференций, посвященных 260-летию Бэйсе хожуна и 250-летию Хемчикского хошуна. 24 октября 2014 г., 29 апреля 2015 г.] / отв. ред отв. ред. С. М. Орус-оол. Кызыл : ОАО «Тываполиграф». 188 с. С. 105-107.

Николаева, Т. В. (1983) Изображения на плитах оград тагарской культуры (методика и хронология) : дисс. ... к. и. н. Кемерово. 241 с.

Панкова, С. В. (2008) «Фигуры-лопасти» на таштыкских изображениях лошадей // Тропою тысячелетий [Сборник к юбилею М.А. Дэвлет] / под. ред. Д. Г. Савинова, О. С. Советова. Кемерово : Кузбассвузиздат. Вып. IV. 188 с. C. 106-114.

Полторацкая, В. Н. (1962) Знаки на предметах из курганов эпохи ранних кочевников в Горном Алтае // Археологический сборник / под. ред. М. И. Артамонова. Л. : б. и. Вып. 5. 124 с. С. 76-90.

Радлов, В. В. (1905) Опыт словаря тюркских наречий / СПб. : ИАН. Т. 3. 1204 с.

Рогожинский, А. Е. (2016) Знаки собственности и власти древних и средневековых обитателей Казахской степи // Археологическое наследие Сибири и Центральной Азии (проблемы интерпретации и сохранения): материалы международной конференции / под ред. В. В. Боброва. Кемерово : Кузбассвузиздат. 360 с. С. $53-63$.

Руденко, С. И. (1952) Горноалтайские находки и скифы. М. - Л. : Изд-во АН СССР. 268 с.

Рыгдалон, Э. Р. (1959) Писаницы близ оз. Шира // Советская археология. М. : АН СССР. № XXIX-XXX. 407 с. C. 186-202.

Савинов, Д. Г. (1976) К вопросу о хронологии и семантике изображений на плитах оград тагарских курганов (по материалам могильников у горы Туран) // Южная Сибирь в скифо-сарматскую эпоху / отв. ред. А. И. Мартынов. Кемерово : б. и.. 118 с. С. $57-72$.

Савинов, Д. Г. (1994) Развитие стиля изображений на плитах курганов тагарской культуры // Проблемы археологии / отв. ред. В. М. Массон. СПб. : СПбГУ. Вып. 3. 184 с. С. 123-136.

Семенов, Вл. А., Килуновская, М. Е., Красниенко, С. В., Субботин, А. В. (2003) Изображения на плитах тагарских курганов / отв. ред. В. М. Массон. СПб. : ИИМК РАН. 122 с.

Тамги доисламской Центральной Азии (2019) / рук. проекта Д. А. Воякин. Самарканд : МИЦАИ. 452 с.

Тишин, В. В. (2018) Некоторые вопросы изучения тамг кочевников Центральной Азии древнетюркского времени // Труды Института востоковедения РАН / отв. ред. Д. Д. Васильев. М. : Институт востоковедения РАН. № 7. 268 c. C. $101-113$.

Тюлюш, А. Ч. (2014) Традиция тамгапользования у тюркских народов (тувинцев) // Актуальные проблемы гуманитарных и естественных наук. № 8-1. С. 78-80.

Тюлюш, А. Ч. (2015) Типология родовых тамг у тувинцев // Известия Алтайского государственного университета. Алтайский государственный университет. (Барнаул): Вып. Исторические науки и Археология. № 4-2 (88). C. 202-206.

Тюлюш, А. Ч. (2016) История бытования тамговых знаков у тюрков Саяно-Алтая // Вестник Томского государственного университета. № 411. C. 158-164. DOI: www.doi.org/10.17223/15617793/411/21

Чадамба, Л. Д. (2009) Современное состояние памятника наскального искусства Малый Баян-Кол (Республика Тува) [Электронный ресурс] // Новые исследования Тувы. №3. С. 197-209. URL: https:/nit.tuva.asia/nit/article/ view/639 (дата обращения: 12.09.2020)

Черемисин, Д. В. (2002) Исследование наскальных изображений долины реки Чаганка (Алтай) в 2001 г. // Вестник Сибирской ассоциации исследователей первобытного искусства. Вып. 4. С. 12-16.

Черемисин, Д. В. (2004) Результаты новейших исследований петроглифов древнетюркской эпохи на юговостоке Российского Алтая // Археология, этнография, антропология Евразии. № 1 (17). С. 40-51.

Членова, Н. Л. (2000) Олени, кони и копыта (О связях Монголии, Казахстана и Средней Азии в скифскую эпоху) // Российская археология. № 1. С. 90-106.

Чугунов, К. В., Парцингер, Г., Наглер, А. (2017) Царский курган скифского времени Аржан-2 в Туве. Новосибирск : ИАЭТ СО РАН. 500 с.

Щербак, А. М. (2001) Тюркская руника. Происхождение древнейшей письменности тюрок, границы ее распространения и особенности использования. СПб. : Наука. 147 с.

Ямаева, Е. Я. (2004) Родовые тамги алтайских тюрок XIX-XX вв. Горно-Алтайск : б. и. 56 с.

Яценко, С. А. (2001) Знаки-тамги ираноязычных народов древности и средневековья / ред. изд. В. В. Волгина. М. : Восточная литература. 189 с. 
Appelgren-Kivalo, H. (1931) Alt-altaische Kunstdenkmäler. Helsingfors. 120 p.

Čugunov, K. V., Parzinger, H., Nagler, A. (2006) Der Goldschatz von Aržan. Ein Fürstengrab der Skythenzeit in der südsibirischen Steppe. München. 144 s.

Čugunov, K., Parzinger, H., Nagler, A. (2010) Der skythenzeitliche Fürstenkurgan Aržan 2 in Tuva. Mainz : Philipp von Zabern. $330 \mathrm{~s}$.

Дата поступления: 15.12.2020 2.

\section{REFERENCES}

Adrianov, A. V. (1886) Puteshestvie na Altai i za Saiany, sovershennoe v 1881 g. po porucheniiu Imperatorskogo Russkogo geograficheskogo obshchestva [A Journey to the Altai and beyond the Sayans, made in 1881 on behalf of the Imperial Russian Geographical Society] / Zapiski IRGO po obshchei geografii. St. Petersburg, Tip. Imp. Akad. nauk, T. XI. 444 p. (In Russ).

Adyg-Tiuliush, L. S. (2017) Tyva chonnung ugulzalary, kheeleri [Ornaments of Tuvan people]. Novosibirsk, s. n. 180 p. (In Tuv.).

Batmanov, I. A., Aragachi Z. B. and Babushkin G. F. (1962) Sovremennaia i drevniaia eniseika [Modern and ancient Yeniseika]. Frunze, Izdatel'stvo Akademii nauk Kirgizskoi SSR. 249 p. (In Russ.).

Bogatyrev, N. G. (1942) O tuvinskikh pamiatnikakh drevnosti [On Tuvan monuments of antiquity]. Pod znamenem Lenina - Stalina, no. 2, pp. 97-104. (In Russ.).

Vainshtein, S. I. (1972) Istoricheskaia etnografiia tuvintsev. Problemy kochevogo khoziaistva [Historical ethnography of Tuvans. Problems of nomadic economy]. Moscow, Nauka. 314 p. (In Russ.).

Vainshtein, S. I. (1974) Istoriia narodnogo iskusstva Tuvy [A history of folk art in Tuva]. Moscow, Nauka. 223 p. (In Russ.).

Vasil'ev, D. D. (1983) Korpus tiurkskikh runicheskikh pamiatnikov basseina Eniseia [The corpus of the Turkic Runic monuments of the Yenisei basin] / ed. by S. G. Kliashtornyi. Leningrad, Nauka. 128 p. (In Russ.).

Vasil'ev, D. D. (2015) Drevnetiurkskie nadpisi i petroglify Iuzhnoi Sibiri kak istochnik po istorii periferii Tiurkskogo kaganata [Ancient Turkic inscriptions and petroglyphs of Southern Siberia as a source on the history of the periphery of the Turkic Khaganate]. In: Aktual'nye voprosy arkheologii i etnologii Tsentral'noi Azii [Topical issues of Archaeology and Ethnology of Central Asia]: Proceedings of the International Scientific Conference / ed. by Bazarov B. V. Irkutsk, Ottisk Publ. 504 p. Pp. 361-366. (In Russ.).

Grach, A. D. (1968) Drevneishie tiurkskie pogrebeniia s sozhzheniem v Tsentral'noi Azii [The oldest Turkic fire burials in Central Asia]. In: Istoriia, arkheologiia i etnografiia Srednei Azii [History, archaeology and ethnography of Central Asia] / editorial board: A. V. Vinogradov et al. Moscow, Nauka. 368 p. Pp. 207-213. (In Russ.).

Darzha, V. Ch. (2003) Loshad' v traditsionnoi praktike tuvintsev-kochevnikov [The horse in the traditional practice of the Tuvan nomads] / ed. by G. N. Kurbatskii. Kyzyl, TuvIKOPR SO RAN. 184 p. (In Russ.).

Dongak, S. Ch. (2010) Nekotorye aspekty izucheniia tuvinskikh tamg [Some aspects of the study of Tuvan Tamgs]. In: Problemy etnicheskoi istorii i kul'tury tiurko-mongol'skikh narodov [Problems of ethnic history and culture of the TurkicMongolian peoples]: a collection of articles / ed. by E. P. Bakaeva. Elista, KIGI RAN. Vol. II. 207 p. Pp. 151-157. (In Russ.).

Dulov, V. I. (1956) Sotsial'no-ekonomicheskaia istoriia Tuvy. XIX - nachalo XX v. [The socio-economic history of Tuva: $19^{\text {th }}$ - early $20^{\text {th }}$ centuries]. Moscow, Akademia nauk SSSR Publ. 608 p. (In Russ.).

Devlet, M. A. (1976) Petroglify Ulug-Khema [Petroglyphs of Ulug-Khem] / ed. by V. V. Volkov. Moscow, Nauka. 120 p. (In Russ.).

Devlet, M. A. (1980) Petroglify Mugur-Sargola [Petroglyphs of Mugur-Sargol] / ed. by V. V. Volkov. Moscow, Nauka. 271 p. (In Russ.).

Devlet, M. A. (1996) Petroglify Eniseia. Istoriia izucheniia (XVIII - nachalo XX vv.) [Petroglyphs of the Yenisei: History of studying, $18^{\text {th }}$ to early $20^{\text {th }}$ centuries)]. Moscow, IA RAN. 249 p. (In Russ.).

Devlet, M. A. (1998) Petroglify na dne Saianskogo moria (gora Aldy-Mozaga) [Petroglyphs at the bottom of the Sayan Sea (Mount Aldy-Mozaga)] / ed. by V. V. Volkov. Moscow, Pamiatniki istoricheskoi mysli. 287 p. (In Russ.).

Devlet, M. A. (2004) Kamennyi «kompas»v Saianskom kan'one Eniseia [A stone "compass" in the Sayan canyon of the Yenisei]. Moscow, Nauchnyi mir. 88 p. (In Russ.).

Devlet, M. A. (2009) Mozaga-Komuzhap - pamiatnik naskal'nogo iskusstva v zone zatopleniia Saianskoi GES [MozagaKomuzhap, a monument of rock art in the floodzone the Sayan hydro power plant] / ed. by M. F. Kosarev. Moscow, Institut arkheologii RAN. 216 p. (In Russ.).

Istoriia Tuvy [The History Of Tuva] (2007): in 3 vols. / ed. by V. A. Lamin. Novosibirsk, Nauka. Vol. 2. 430 p. (In Russ.).

Istoriia Tuvy [The History Of Tuva] (2016): in 3 vols. / ed. by V. A. Lamin. Novosibirsk, Nauka. Vol. 3. 455 p. (In Russ.). 
Katanov, N.F. (2011) Ocherki uriankhaiskoi zemli. Dnevnik puteshestviia, ispolnennogo v 1889 godu [Essays on the Uriankhai territory. Diary of a journey made in 1889]. Preparation of the manuscript for printing, introduction and commentary by A. K. Kuzhuget. Kyzyl : TIGPI pri Pravitel'stve RT. 383 p. (In Russ.).

Kitova, L. Yu. (2007) Semantika znaka kopyta na tagarskoi bronze [Semantics of the hoof sign on Tagar bronze]. In: Kamennaia skul'ptura i melkaia plastika drevnikh i srednevekovykh narodov Evrazii [Stone sculpture and small statuary among ancient and medieval peoples of Eurasia] : a collection of articles / ed. by A. A. Tishkin. Vol. 3. Barnaul, Azbuka. 156 p. Pp. 28-30. (In Russ.).

Kliashtornyi, S. G. (1980) Runicheskaia nadpis' na kamennom izvaianii iz Choirena [A runic inscription on a stone statue from Choiren]. In: Strany i narody Vostoka [Countries and peoples of the East] / ed. by V. A. Romodin. Moscow, Nauka. Vol. XXII. Sredniaia i Tsentral'naia Aziia. Geografiia, etnografiia, istoriia [Central Asia. Geography, ethnography, history]. 278 p. Pp. 90-102. (In Russ.).

Kormushin, I. V. (1997) Tiurkskie eniseiskie epitafii. Teksty i issledovaniia [Turkic epitaphs of the Yenisei area. Texts and studies], ed. by E. R. Tenishev. Moscow, Nauka. 303 p. (In Russ.).

Korol'kova, E. F. (2006) Zverinyi stil' Evrazii. Iskusstvo plemen Nizhnego Povolzh'ia i Iuzhnogo Priural'ia v skifskuiu epokhu (VII-IV vv. do n. e.) [The Animal style in Eurasia. Art of the tribes of the Lower Volga Region and the Southern Urals in the Scythian era, $7^{\text {th }}$ to $4^{\text {th }}$ C. BC)]. St. Petersburg, Peterburgskoe Vostokovedenie. 272 p. (In Russ.).

Kocheev, V. A. (1994) Znaki na strelakh (K voprosu o naznachenii tamgoobraznykh znakov na kostianykh nakonechnikakh strel iz kurganov Gornogo Altaia skifskogo vremeni) [Signs on arrows: The purpose of tamga-like signs on bone arrowheads from the mounds of the Gorny Altai of the Scythian time)]. In: Problemy izucheniia kul'turno-istoricheskogo naslediia Altaia [Problems of studying the cultural and historical heritage of the Altai] / ed. by V. N. Elin. Gorno-Altaisk, Agentstvo po kul'turno-istoricheskomu naslediiu Respubliki Altai. 117 p. Pp. 57-59. (In Russ.).

Kubarev, V. D. (2007) Kalbak-tash II: pamiatnik naskal'nogo iskusstva Altaia [Kalbak-Tash II: a monument of rock art of the Altai]. In: Problemy arkheologii, etnografii, antropologii Sibiri i sopredel'nykh territorii [Problems of archaeology, ethnography, anthropology of Siberia and adjacent territories]. Proceedings of the Annual Session of the IAET SB RAS 2007 / ed. by A. P. Derevianko and V. I. Molodin. Novosibirsk, Izd-vo Instituta arkheologii i etnografii SO RAN. Vol. XIII. 524 p. Pp. 282-287. (In Russ.).

Kubarev, V. D. (1979) Novye svedeniia o drevnetiurkskikh ogradkakh Vostochnogo Altaia [New information about the ancient Turkic fencelets in the Eastern Altai]. In: Novoe v arkheologii Sibiri i Dal'nego Vostoka [New discoveries in the Archeology of Siberia and the Far East] / ed. by A. P. Pogozhev. Novosibirsk, Nauka. 237 p. Pp. 135-160. (In Russ.).

Kuz'mina, E. E. (1979) Drevneiranskie i peredneaziatskie elementy v iskusstve iranoiazychnykh narodov pervoi poloviny I tys. do n. e. [Ancient Iranian and Near-Asian elements in the art of the Iranian-speaking peoples of the first half of the $1^{\text {st }}$ millennium BC]. In: Tezisy dokladov III Vsesoiuznoi konferentsii «Iskusstvo i arkheologiia Irana i ego sviaz' $s$ iskusstvom narodov SSSR s drevneishikh vremen» [Paper abstracts of the $3^{\text {rd }}$ All-Union Conference "Art and Archeology of Iran in its connection with the art of the peoples of the USSR since ancient times"] / ed. by R. M. Polikarpov. Moscow, Sovetskii khudozhnik. 96 p. Pp. 42-45. (In Russ.).

Kubarev, V. D. (1987) Kurgany Ulandryka [The Kurgans of Ulandryk] / ed. by V. E. Medvedev. Novosibirsk, Institut istorii, filologii i filosofii SO RAN. 300 ps. (In Russ.).

Kyzlasov, L. R. (1977) «Drevnetiurkskie» neuriaditsy [“Ancient Turkic” turmoil]. Sovetskaia tiurkologiia, no. 5, pp. 44-46. (In Russ.).

Kyzlasov, L. R. (1960) Novaia datirovka pamiatnikov eniseiskoi pis'mennosti [A new dating of texts in the Yenisei script]. Sovetskaia arkheologiia, no. 3, pp. 93-120. (In Russ.).

Kyzlasov, L. R. and Leont'ev, N. V. (1980) Narodnye risunki khakasov [Folk drawings of the Khakass] / ed. by L. S. Efimova. Moscow, Nauka. 176 p. (In Russ.).

Mongush, B. B. (2015a) Beezi kozhuunnnung 17 sumularynyng tangmalary [Tamgas of 17 sumans of Beise Khozhun]. In: Töögüge daianmyshaan - kelir üezhe [With the aid on historical knowledge, into the future]: Proceedings of research conferences dedicated to the 260th anniversary of Beise Khozhun and the 250th anniversary of Khemchik khoshun. October 24, 2014, April 29, 2015 / ed. by S. M. Orus-ool. Kyzyl, OAO «Tyvapoligraf». 188 p. Pp. 13-16. (In Tuv.).

Mongush, B. B. (2015b) Khemchik kozhuunnnung 10 sumularynyng tangmalary [Tamgas of 17 sumans of Basee Khoshun]. In: Töögüge daianmyshaan - kelir üezhe [Relying on historical knowledge-into the future]: Proceedings of research conferences dedicated to the 260th anniversary of Beise Khozhun and the 250th anniversary of Khemchik khoshun. October 24, 2014, April 29, 2015 / ed. by S. M. Orus-ool. Kyzyl, OAO «Tyvapoligraf». 188 p. Pp. 105-107. (In Tuv.).

Nikolaeva, T. V. (1983) Izobrazheniia na plitakh ograd tagarskoi kul'tury (metodika i khronologiia) [Imagekн on the plates of the fences of the Tagar culture: methodology and chronology]: Diss. ... Candidate of History. Kemerovo. 241 p. (In Russ.). 
Pankova, S. V. (2008) «Figury-lopasti» na tashtykskikh izobrazheniiakh loshadei ["Bladed figures on Tashtyk horse imagery]. In: Tropoiu tysiacheletii [A millennia-old trail]: A collection for the anniversary of M. A. Devlet / ed. by D. G. Savinova and O. S. Sovetova. Kemerovo, Kuzbassvuzizdat. Vol. IV. 188 p. Pp. 106-114. (In Russ.).

Poltoratskaia, V. N. (1962) Znaki na predmetakh iz kurganov epokhi rannikh kochevnikov v Gornom Altae [Signs on objects from the mounds of the early Nomad era in the Altai Mountains]. In: Arkheologicheskii sbornik [Archaeological collection] / ed. by M. I. Artamonova. Leningrad, s. n. Vol. 5. 124 p. Pp. 76-90. (In Russ.).

Radlov, V.V.(1905) Opyt slovarya tyurkskikh narechii [An attempt at a dictionary of Turkic dialects]. In 4 vols. St. Petersburg, Imperial Acad. of Sc. Vol. III. 2203 columns. (In Turkic).

Rogozhinskii, A. E. (2016) Znaki sobstvennosti i vlasti drevnikh i srednevekovykh obitatelei Kazakhskoi stepi [Signs of ownership and power among ancient and medieval inhabitants of the Kazakh steppe]. In: Arkheologicheskoe nasledie Sibiri i Tsentral'noi Azii (problemy interpretatsii i sokhraneniia) [Archaeological heritage of Siberia and Central Asia: problems of interpretation and preservation]: Proceedings of an international conference / ed. by V. V. Bobrov. Kemerovo, Kuzbassvuzizdat. 360 p. Pp. 53-63. (In Russ.).

Rudenko, S. I. (1952) Gornoaltaiskie nakhodki i skify [The Gorny Altai finds and the Scythians]. Moscow, Leningrad, Izd-vo AN SSSR. 268 p. (In Russ.).

Rygdalon, E. R. (1959) Pisanitsy bliz oz. Shira [Petroglyphs near Lake Shira]. Sovetskaia arkheologiia, no. XXIX-XXX, pp. 186-202. (In Russ.).

Savinov, D. G. (1976) K voprosu o khronologii i semantike izobrazhenii na plitakh ograd tagarskikh kurganov (po materialam mogil'nikov $u$ gory Turan) [On chronology and semantics of imagery on the plates of the fences of Tagar mounds: the case of burial grounds near Mount Turan)]. In: Iuzhnaia Sibir' v skifo-sarmatskuiu epokhu [Southern Siberia in the Scythian-Sarmatian era] / ed. by A. I. Martynov. Kemerovo, s. n. 118 p. Pp. 57-72. (In Russ.).

Savinov, D. G. (1994) Razvitie stilia izobrazhenii na plitakh kurganov tagarskoi kul'tury [The development of the style of imagery on the plates of the Tagar culture mounds]. In: Problemy arkheologii [Problems of Archeology] / ed. by V. M. Masson. St. Petersburg, SPbGU. Vol. 3. 184 p. Pp. 123-136. (In Russ.).

Semenov, Vl. A., Kilunovskaia, M. E., Krasnienko, S. V. and Subbotin, A. V. (2003) Izobrazheniia na plitakh tagarskikh kurganov [Imagery on the plates of Tagarsky mounds] / ed. by V. M. Masson. St. Petersburg, IIMK RAN. 122 p. (In Russ.).

Tamgi doislamskoi Tsentral'noi Azii [Tamgas of pre-Islamic Central Asia] (2019) / head D. A. Voiakin. Samarkand, MITsAI. 452 p. (In Russ.).

Tishin, V. V. (2018) Nekotorye voprosy izucheniia tamg kochevnikov Tsentral'noi Azii drevnetiurkskogo vremeni [Some problems in the study of tamgas of the Old Turkic Central Asia]. In: Trudy Instituta vostokovedeniia RAN [Proceedings of the Institute of Oriental studies, RAS] / ed. by D. D. Vasil'ev. Moscow, Institut vostokovedeniia RAN. № 7. 268 p. Pp. $101-113$. (In Russ.).

Tyulyush, A. Ch. (2014) Traditsiia tamgapol'zovaniia u tiurkskikh narodov (tuvintsev) [The tradition of tamga use among Turkic peoples: the case of Tuvans]. Aktual'nye problemy gumanitarnykh i estestvennykh nauk, no. 8-1, pp. 78-80. (In Russ.).

Tyulyush, A. Ch. (2015) Tipologiia rodovykh tamg u tuvintsev [Typology of Tuvan family tamgas]. Izvestiia Altaiskogo gosudarstvennogo universiteta. Altaiskii gosudarstvennyi universitet. Vol. Istoricheskie nauki i Arkheologiia, no. 4-2 (88), pp. 202-206. (In Russ.).

Tyulyush A. Ch. (2016) Istoriia bytovaniia tamgovykh znakov u tiurkov Saiano-Altaia [The history of tamga signs among the Turkic peoples of the Sayan-Altai]. Vestnik Tomskogo gosudarstvennogo universiteta, no. 411, pp. 158-164. (In Russ.). DOI: www.doi.org/10.17223/15617793/411/21

Chadamba, L. D. (2009) Sovremennoe sostoianie pamiatnika naskal'nogo iskusstva Malyi Baian-Kol (Respublika Tuva) [The current state of petroglyphic relics in Maly Bayan-Kol, Republic of Tuva]. New Research of Tuva, no. 3, pp. 197-209 [online] Available at: https://nit.tuva.asia/nit/article/view/639 (access date: 12.09.2020) (In Russ.).

Cheremisin, D. V. (2002) Issledovanie naskal'nykh izobrazhenii doliny reki Chaganka (Altai) v $2001 \mathrm{~g}$. [The study of rock paintings of the Chaganka River valley (Altai) in 2001]. Vestnik Sibirskoi assotsiatsii issledovatelei pervobytnogo iskusstva, vol. 4, pp. 12-16. (In Russ.).

Cheremisin, D. V. (2004) Rezul'taty noveishikh issledovanii petroglifov drevnetiurkskoi epokhi na iugo-vostoke Rossiiskogo Altaia [The outcomes of the latest research on petroglyphs of the Ancient Turkic era in the south-east of the Russian Altai]. Arkheologiia, etnografiia, antropologiia Evrazii, no. 1 (17), pp. 40-51. (In Russ.).

Chlenova, N. L. (2000) Oleni, koni i kopyta (O sviaziakh Mongolii, Kazakhstana i Srednei Azii v skifskuiu epokhu) [Deer, horses and hooves: on the links between Mongolia, Kazakhstan and Central Asia in the Scythian era)]. Rossiiskaia arkheologiia, no. 1, pp. 90-106. (In Russ.). 
Chugunov, K. V., Partsinger G. and Nagler A. (2017) Tsarskii kurgan skifskogo vremeni Arzhan-2 v Tuve [Arzhan II, the princely mound of the Scythian time in Tuva]. Novosibirsk, IAET SO RAN. 500 p. (In Russ.).

Shcherbak, A. M. (2001) Tiurkskaia runika. Proiskhozhdenie drevneishei pis'mennosti tiurok, granitsy ee rasprostraneniia $i$ osobennosti ispol'zovaniia [The Turkic runic: The origin of the oldest writing system of the Turks, the boundaries of its distribution and features of use]. St. Petersburg, Nauka. 147 p. (In Russ.).

Iamaeva, E. Ya. (2004) Rodovye tamgi altaiskikh tiurok XIX-XX vv. [Family teneric tamgas of the $19^{\text {th }}-20^{\text {th }}$ century Turkic peoples of the Altai]. Gorno-Altaisk, s. n. 56 p. (In Russ.).

Yatsenko, S. A. (2001) Znaki-tamgi iranoiazychnykh narodov drevnosti i srednevekov'ia [The tamgas of the Iranian-speaking peoples in the antiquity and the Middle ages] / ed. by V. V. Volgin. Moscow, Vostochnaia literatura. 189 p. (In Russ.).

Appelgren-Kivalo, H. (1931) Alt-altaische Kunstdenkmäler. Helsingfors. 120 p.

Čugunov, K.V., Parzinger, H. and Nagler, A. (2006) Der Goldschatz von Aržan. Ein Fürstengrab der Skythenzeit in der südsibirischen Steppe. München. 144 s.

Čugunov, K., Parzinger, H. and Nagler, A. (2010) Der skythenzeitliche Fürstenkurgan Aržan 2 in Tuva. Mainz, Philipp von Zabern. $330 \mathrm{~s}$.

Submission date: 15.12.2020. 